\title{
Modulation of Neurotransmission by GPCRs Is Dependent upon the Microarchitecture of the Primed Vesicle Complex
}

\author{
Edaeni Hamid, ${ }^{1}$ Emily Church, ${ }^{1}$ Christopher A. Wells, ${ }^{2}$ Zack Zurawski, ${ }^{2}$ Heidi E. Hamm, ${ }^{2}$ and Simon Alford ${ }^{1}$ \\ ${ }^{1}$ Department of Biological Sciences, University of Illinois at Chicago, Chicago, Illinois 60607 and ${ }^{2}$ Department of Pharmacology, Vanderbilt University \\ Medical School, Nashville, Tennessee 37232
}

$\mathrm{G}_{\mathrm{i} / \mathrm{o}}$-protein-coupled receptors (GPCRs) ubiquitously inhibit neurotransmission, principally via $\mathrm{G} \beta \gamma$, which acts via a number of possible effectors. GPCR effector specificity has traditionally been attributed to $\mathrm{G} \alpha$, based on $\mathrm{G} \alpha$ 's preferential effector targeting in vitro compared with $\mathrm{G} \beta \gamma$ 's promiscuous targeting of various effectors. In synapses, however, $\mathrm{G} \beta \gamma$ clearly targets unique effectors in a receptordependent way to modulate synaptic transmission. It remains unknown whether $\mathrm{G} \beta \gamma$ specificity in vivo is due to specific $\mathrm{G} \beta \gamma$ isoformreceptor associations or to spatial separation of distinct $\mathrm{G} \beta \gamma$ pathways through macromolecular interactions. We thus sought to determine how $\mathrm{G} \beta \gamma$ signaling pathways within axons remain distinct from one another. In rat hippocampal $C A 1$ axons, $\mathrm{GABA}_{\mathrm{B}}$ receptors $\left(\mathrm{GABA}_{\mathrm{B}} \mathrm{Rs}\right)$ inhibit presynaptic $\mathrm{Ca}^{2+}$ entry, and we have now demonstrated that $5-\mathrm{HT}_{1 \mathrm{~B}}$ receptors $\left(5-\mathrm{HT}_{1 \mathrm{~B}} \mathrm{Rs}\right)$ liberate $\mathrm{G} \beta \gamma$ to interact with SNARE complex $\mathrm{C}$ terminals with no effect on $\mathrm{Ca}^{2+}$ entry. Both $\mathrm{GABA}_{\mathrm{B}} \mathrm{Rs}$ and $5-\mathrm{HT}_{1 \mathrm{~B}} \mathrm{Rs}^{2}$ inhibit $\mathrm{Ca}^{2+}$-evoked neurotransmitter release, but 5- $\mathrm{HT}_{1 \mathrm{~B}} \mathrm{Rs}$ have no effect on $\mathrm{Sr}^{2+}$-evoked release. $\mathrm{Sr}^{2+}$, unlike $\mathrm{Ca}^{2+}$, does not cause synaptotagmin to compete with $\mathrm{G} \beta \gamma$ binding to SNARE complexes. 5- $\mathrm{HT}_{1 \mathrm{~B}} \mathrm{Rs}$ also fail to inhibit release following cleavage of the $\mathrm{C}$ terminus of the SNARE complex protein SNAP-25 with botulinum A toxin. Thus, $\mathrm{GABA}_{\mathrm{B}} \mathrm{Rs}$ and $5-\mathrm{HT}_{1 \mathrm{~B}} \mathrm{Rs}$ both localize to presynaptic terminals, but target distinct effectors. We demonstrate that disruption of SNARE complexes and vesicle priming with botulinum C toxin eliminates this selectivity, allowing $5-\mathrm{HT}_{1 \mathrm{~B}} \mathrm{R}$ inhibition of $\mathrm{Ca}^{2+}$ entry. We conclude that receptor-effector specificity requires a microarchitecture provided by the SNARE complex during vesicle priming.

\section{Introduction}

$\mathrm{G}_{\mathrm{i} / \mathrm{o}}$-protein-coupled receptor (GPCR)-dependent presynaptic inhibition occurs at all synapses, but is mediated by multiple mechanisms directly involved in evoked exocytosis. The most investigated mechanism is a membrane-delimited $\mathrm{G} \beta \gamma$ mediated inhibition of presynaptic $\mathrm{Ca}^{2+}$ entry (Herlitze et al., 1996; Ford et al., 1998; Brown and Sihra, 2008). G $\beta \gamma$ might also activate presynaptic G-protein inwardly rectifying channels (Michaeli and Yaka, 2010) and can modulate neurotransmission by directly interacting with the SNARE complex without altering $\mathrm{Ca}^{2+}$ entry (Blackmer et al., 2001; Takahashi et al., 2001; Gerachshenko et al., 2005). A region of the SNARE complex C terminus provides a target for the $\mathrm{Ca}^{2+}$ sensor synaptotagmin during the induction of exocytosis (Zhang et al., 2002). $\mathrm{G} \beta \gamma$ competition with $\mathrm{Ca}^{2+}$-synaptotagmin at this region mediates presynaptic inhibition (Gerachshenko et al.,

Received July 30, 2012; revised Nov. 8, 2013; accepted Nov. 12, 2013.

Author contributions: E.H. and S.A. designed research; E.H., E.C., C.A.W., Z.Z., and S.A. performed research; E.H., E.C., C.A.W., Z.Z., H.E.H., and S.A. analyzed data; E.H., H.E.H., and S.A. wrote the paper.

This work is supported by National Institute of Neurological Disorders and Stroke, R01NS52699 and MH84874 to S.A., F31NS063662 to E.H., and R01EY010291 to H.E.H. We thank J. Richmond, T. Searl, M. Alpert, E. Church, and S. Ramachandran for critical reading of this manuscript and invaluable discussions.

The authors declare no competing financial interests.

Correspondence should be addressed to Simon Alford, Department of Biological Sciences, University of Illinois at Chicago, 840 West Taylor Street, Chicago, IL 60607. E-mail: sta@uic.edu.

E. Hamid's present address: National institute of Stroke and Neurological Disorders, 35 Convent Drive, 35/2B-814, Bethesda, MD 20892.

DOI:10.1523/JNEUROSCI.3633-12.2014

Copyright $\odot 2014$ the authors $\quad 0270-6474 / 14 / 340260-15 \$ 15.00 / 0$
2005, 2009; Yoon et al., 2007; Wells et al., 2012). This region of the SNARE complex is also important for vesicle fusion. Cleavage of the $\mathrm{C}$ terminus of SNAP-25 with botulinum toxin A (BoNT/A) modifies fusion pore formation (Fang et al., 2008), and prevents GPCR-mediated inhibition (Gerachshenko et al., 2005; Delaney et al., 2007). Indeed, $\mathrm{Ca}^{2+}$ synaptotagmin interaction with the SNARE complex may mediate fusion pore expansion (Lai et al., 2013).

Mechanisms that target presynaptic $\mathrm{Ca}^{2+}$ channels and those that interact with the SNARE complex signal with $G \beta \gamma$, but it is unknown whether, or how, $G \beta \gamma$-selective targeting of closely localized effectors can occur. In the case of $5-\mathrm{HT}_{1 \mathrm{~B}}$ receptors $\left(5-\mathrm{HT}_{1 \mathrm{~B}} \mathrm{Rs}\right)$, it has been shown that $5-\mathrm{HT}_{1 \mathrm{~B}} \mathrm{Rs}$ target $\mathrm{Ca}^{2+}$ channels in the calyceal synapse of Held (Mizutani et al., 2006), but the $\mathrm{C}$ terminus of the SNARE complex in lamprey synapses (Gerachshenko et al., 2005) and chromaffin cells (Blackmer et al., 2005). $\mathrm{GABA}_{\mathrm{B}} \mathrm{Rs}$ inhibit $\mathrm{Ca}^{2+}$ entry in the Calyx synapse of Held (Takahashi et al., 1998, 2005) and in hippocampal neurons (Wu and Saggau, 1995). Other GPCRs also target either SNARE complexes or $\mathrm{Ca}^{2+}$ channels, for example, noradrenergic-a ${ }_{2 \mathrm{~A}}$ receptors target the SNARE complex in the amygdala (Delaney et al., 2007), but may modulate $\mathrm{Ca}^{2+}$ channels in sensory neurons (Dunlap and Fischbach, 1978). Finally, $\mathrm{GABA}_{\mathrm{B}}$ Rs also inhibit spontaneous neurotransmitter release events independently of $\mathrm{Ca}^{2+}$ (Scanziani et al., 1992; Kabashima et al., 1997), an effect that was first shown for adenosine at the neuromuscular junction (Silinsky, 1984) and later in cortex (Cox et al., 2000). However, effects on spontaneous release may not directly involve evoked release 
(Wang and Armstrong, 2012), because spontaneous release can be mediated through independent pathways (Kavalali et al., 2011).

If two mechanisms, for example, $\mathrm{G} \beta \gamma / \mathrm{SNARE}$ complex interactions and $\mathrm{G} \beta \gamma / \mathrm{Ca}^{2+}$ channel interactions, coexist in one terminal, it raises fundamental questions about targeting of modulatory systems. Are G $\beta \gamma$ effectors selectively targeted and, if so, are effector identities determined by $\mathrm{G} \beta \gamma$ properties or ultrastructurally with similar receptors and effectors as components of molecular machines? We demonstrate that two GPCRs, both $\mathrm{G} \alpha_{\mathrm{i} / \mathrm{o}}$ coupled, using membrane-delimited mechanisms and which both inhibit CA1 to subicular excitation modulate neurotransmitter release through different effectors whose targets are governed by the microarchitecture of SNARE complexes during vesicle priming.

\section{Materials and Methods}

Hippocampal slice preparation. Hippocampal slices (300 $\mu \mathrm{M}$ thickness) were prepared from 17- to 23-d-old male Sprague Dawley rats anesthetized with isoflurane and decapitated in accordance with institutional guidelines. All recordings were in the following solution (mM): $124 \mathrm{NaCl}$, $26 \mathrm{NaHCO}_{3}, 1.25 \mathrm{NaH}_{2} \mathrm{PO}_{4}, 3 \mathrm{KCl}, 2 \mathrm{CaCl}_{2}, 1 \mathrm{MgCl}_{2}$, and 10 D-glucose, bubbled with $95 \% \mathrm{O}_{2}-5 \% \mathrm{CO}_{2}$. Recordings were at $28^{\circ} \mathrm{C}$ maintained by a flow heating system of the superfusate, which was constantly superfused over the preparation at $1-2 \mathrm{ml} / \mathrm{min}$ for all recordings. All pharmacological agents applied extracellularly were added to the superfusate.

Electrophysiology. In hippocampal slices, CA1 and subicular pyramidal neurons were whole-cell clamped following microscopic visual identification under an upright microscope with the same lens used for imaging experiments. For postsynaptic subicular pyramidal cell recordings, patch pipettes $(\sim 4 \mathrm{M} \Omega)$ contained solution of the following composition (in mM): $146 \mathrm{CsSO}_{3}, 2 \mathrm{MgCl}_{2}, 5$ EGTA, and 9.1 HEPES, adjusted to $\mathrm{pH} 7.2$ with $\mathrm{CsOH}$. For imaging experiments recording from CA1 pyramidal neurons, the pipette composition was as follows (in $\mathrm{mm}$ ): $146 \mathrm{KSO}_{3}, 2$ $\mathrm{MgCl}_{2}, 0.025 \mathrm{EGTA}$, and 9.1 HEPES, adjusted to $\mathrm{pH} 7.2$ with $\mathrm{KOH}$. Dyes were included in the patch solution (Fluo-5F, $200 \mu \mathrm{M}$; Alexa 594 hydrazide, $250 \mu \mathrm{M}$ ). Series resistance was monitored throughout the experiment by application of a $5 \mathrm{mV}$ voltage step and recordings were discarded if the series resistance changed by $>10 \%$ during the course of the experiment. All holding potentials for whole-cell voltage-clamp recordings were at $-70 \mathrm{mV}$. For current-clamp recordings the membrane potential was maintained between -70 and $-80 \mathrm{mV}$. Liquid junction potentials were not corrected. EPSCs in subicular neurons were evoked with focal stimuli $(0.2 \mathrm{~ms},<20 \mu \mathrm{A})$ to CA1 axons using glass-insulated tungsten microelectrodes.

Detection of spontaneous miniature EPSCs. Spontaneous miniature EPSCs (mEPSCs) and asynchronous events in $\mathrm{Sr}^{2+}$ were low-pass filtered and digitized $(5 \mathrm{kHz})$. Analysis was performed in Igor Pro (WaveMetrics). Detection and extraction of mEPSCs was semi-automated. Filtered data were differentiated to correct for baseline shifts. Thresholds were determined for differentiated control data and maintained for that cell following agonist application. Detected event amplitudes were mapped back onto raw data for visual comparison of amplitudes with mEPSCs to ensure that the detection algorithm functioned adequately. The algorithm is available from our website (http://alford.bios.uic.edu/Research/software.html). This algorithm was applied for asynchronous events in $\mathrm{Sr}^{2+}$. These events were detected over a time window (20-300 ms poststimulus). Two-population KolmogorovSmirnov goodness-of-fit tests determined statistical significance in cumulative histograms. Data are expressed as means \pm SEM. Student paired two-tailed $t$ tests were used to calculate significance, unless otherwise noted.

Imaging. Line-scan confocal imaging $(500 \mathrm{~Hz}$, modified Bio-Rad MRC 600 confocal scan head attached to a custom microscope, http://alford. bios.uic.edu/Research/software.html) was used for $\mathrm{Ca}^{2+}$ transient recording in presynaptic varicosities following single action potentials stimulated with somatic whole-cell electrodes. Alexa 594 hydrazide was excited at $568 \mathrm{~nm}$. Fluo-5F was separately excited $(488 \mathrm{~nm})$ and imaged in bandpass (510-560 nm). Images were taken separately to ensure no cross-channel bleed-through. This was confirmed with neurons filled with only one dye. No bleed-through image was discernible for either dye to the incorrect channel. Varicosities were identified 20-35 min after whole-cell access by imaging the Alexa 594 hydrazide dye and tracking the axon from the filled soma to its projection into the subiculum. $\mathrm{Ca}^{2+}$ transients at these varicosities were imaged in line scanning mode (500 $\mathrm{Hz}$ ) for up to $1 \mathrm{~s}$ during stimuli to the soma to evoke action potentials. Image analysis was performed within ImageJ except anatomical reconstructions (VoxBlast; VayTek). Line scan images are represented as linear with the applied LUT mapping.

$G \beta \gamma$ competition binding assay. The open reading frames for the SNARE component proteins were subcloned into the pGEX6p1 vector (GE Healthcare) for expression in bacteria as previously described (Yoon et al., 2007). To purify SNARE proteins, recombinant bacterially expressed glutathione $S$-transferase fusion proteins were expressed in Escherichia coli strain BL21(DE3). Protein expression was induced with 0.1 $\mathrm{mm}$ isopropyl $\beta$-D-thiogalactoside for $16 \mathrm{~h}$ at room temperature. Bacterial cultures were pelleted, washed with $1 \times \mathrm{PBS}$, and then resuspended in lysis buffer [ 25 mM HEPES-KOH, pH 8.0, 150 mm KCl, 1 mм EDTA, 0.2 mM PMSF, $10.7 \mu \mathrm{M}$ leupeptin, $1.5 \mu \mathrm{M}$ aprotinin, $1 \mu \mathrm{M}$ pepstatin and $5 \mathrm{~mm}$ $\beta$-mercaptoethanol (BME)]. Cells were lysed with a sonic dismembrator at $4^{\circ} \mathrm{C}, 50 \%$ duty cycle, $20 \mathrm{~s}$ on, $40 \mathrm{~s}$ off, for $5 \mathrm{~min}$ total. GST-SNAP- 25 and GST-H3 (the H3 domain of syntaxin1A) were purified from cleared lysates by affinity chromatography on glutathione Sepharose beads (GE Healthcare), following the manufacturer's instructions. While the proteins were bound to the beads, the beads were batch washed with two bed volumes of a buffer containing $25 \mathrm{~mm}$ HEPES-KOH, $\mathrm{pH} 8.0,150 \mathrm{~mm}$ $\mathrm{KCl}, 1 \mathrm{~mm}$ EDTA, $1 \%$ Triton X-100, and $5 \mathrm{~mm}$ BME for 5 min at $4^{\circ} \mathrm{C}$. This wash buffer was then exchanged with two bed volumes of a protease buffer containing $25 \mathrm{~mm}$ HEPES, pH 8.0, $150 \mathrm{~mm} \mathrm{KCl,} \mathrm{0.5 \%} \mathrm{n-octyl}$ $\beta$-D-glucopyranoside (OG), $10 \%$ glycerol, $1 \mathrm{~mm}$ EDTA, and $5 \mathrm{~mm} \mathrm{BME}$ in a fresh tube for $5 \mathrm{~min}$ at $4^{\circ} \mathrm{C}$. For GST-SNAP- 25 on beads, the SNAP-25 was eluted by cleaving from GST with PreScission protease (GE Healthcare) overnight at $4^{\circ} \mathrm{C}$ in one bed volume of the protease buffer. Protein concentrations were determined with a Bradford assay kit (Pierce), and purity was verified by SDS/PAGE analysis.

For binary t-SNARE complex assembly a molar excess of $4 \mu \mathrm{M}$ SNAP-25 was mixed with $3 \mu \mathrm{M}$ GST-H3 on glutathione Sepharose beads in a buffer containing $25 \mathrm{~mm}$ HEPES, pH 8.0, $150 \mathrm{~mm} \mathrm{KCl}, 0.25 \%$ OG, $10 \%$ glycerol, $5 \mathrm{~mm}$ BME, and $1 \mathrm{~mm}$ EDTA overnight at $4{ }^{\circ} \mathrm{C}$ with gentle mixing. The binary t-SNARE complex was washed three times with protease buffer and eluted from the column by GST proteolytic cleavage with PreScission protease (GE Healthcare) for $4 \mathrm{~h}$ at $4^{\circ} \mathrm{C}$ as described above. Equimolar protein-protein interaction was confirmed by SDS-PAGE/ Coomassie staining analysis.

$\mathrm{G} \beta_{1} \gamma_{1}$ was purified from bovine retina as previously described (Mazzoni et al., 1991). Fluorescence labeling of $\mathrm{G} \beta_{1} \gamma_{1}$ and binding assays were conducted as described previously (Phillips and Cerione, 1991). Briefly, purified $\mathrm{G} \beta_{1} \gamma_{1}$ was dialyzed into labeling buffer (20 mM HEPES, pH 7.4, $5 \mathrm{~mm} \mathrm{MgCl}_{2}, 150 \mathrm{~mm} \mathrm{NaCl}$, and 10\% Glycerol), then mixed with 2-(4'Maleimidylanilino) naphthalene-6-sulfonic acid (MIANS) in a fivefold molar excess. The reaction proceeded for $3 \mathrm{~h}$ at $4^{\circ} \mathrm{C}$ before quenching with $5 \mathrm{~mm} 2$-mercaptoethanol. The MIANS-G $\beta_{1} \gamma_{1}$ complex was separated from unreacted MIANS using a PD-10 desalting column (GE Healthcare). MIANS-G $\beta_{1} \gamma_{1}$ was stored in aliquots at $-80^{\circ} \mathrm{C}$.

Fluorescence measurements were performed in a fluorescence spectrophotometer (Cary Eclipse) at room temperature. Generally, MIANS$\mathrm{G} \beta_{1} \gamma_{1}$ was diluted into $0.1 \mathrm{ml}$ of assay buffer [20 mM HEPES, pH 7.5, 5 $\mathrm{mm} \mathrm{MgCl}_{2}, 1 \mathrm{~mm}$ dithiothreitol, $0.1 \mathrm{M} \mathrm{NaCl}, 1 \mathrm{~mm}$ EDTA] to a final concentration of $20 \mathrm{~nm}$. The MIANS fluorescence was monitored at an excitation wavelength of $322 \mathrm{~nm}$ and emission of $417 \mathrm{~nm}$. Fluorescence was normalized by expressing all data as $\left(F_{1}-F_{0}\right) / F_{0}$ (where baseline $\mathrm{G} \beta \gamma$ MIANS fluorescence mixed with t-SNARE $=F_{0}$, fluorescence after addition of synaptotagmin $\mathrm{I}=F_{1}$ ) All proteins purified as GST fusion proteins were cleaved from GST with PreScission protease (GE Healthcare) before analysis. The fluorescent changes caused by the addition of SNARE complexes were monitored continuously. Note that the amplitude of the fluorescence increase is not a measure of the affinity of the complex, but rather reflects the specific site on fluorescently labeled $G \beta \gamma$ 
of interaction with each protein. There was no nonspecific binding of the free probe to the SNARE proteins and MIANS-G $\beta \gamma$ was resistant to photobleaching under experimental conditions (data not shown). For $\mathrm{G} \beta \gamma /$ synaptotagmin competition assays, various concentrations of synaptotagmin with SNARE proteins were added to labeled $\mathrm{G} \beta_{1} \gamma_{1}$ with the noted $\mathrm{Ca}^{2+}$ or $\mathrm{Sr}^{2+}$ concentrations, and fluorescence changes were monitored. $\mathrm{EC}_{50}$ concentrations were determined by sigmoidal curve fitting with GraphPad Prism.

\section{Results}

Presynaptic $\mathrm{GABA}_{\mathrm{B}}$ and 5- $\mathrm{HT}_{1 \mathrm{~B}}$ receptors inhibit CA1-subicular synaptic transmission

To demonstrate that $\mathrm{GABA}_{\mathrm{B}} \mathrm{Rs}$ and $5-\mathrm{HT}_{1 \mathrm{~B}} \mathrm{Rs}$ inhibit neurotransmitter release from the same synapses, we stimulated CA1 pyramidal neuron axons in slices $(<20 \mu \mathrm{A}$, $200 \mu \mathrm{s})$ and recorded postsynaptic responses in whole-cell voltage-clamped subicular pyramidal neurons (Fig. 1a). The $\mathrm{GABA}_{\mathrm{A}} \mathrm{R}$ and NMDA receptor antagonists (bicuculline, $5 \mu \mathrm{M}$; D-2 amino-5phosphonopentanoate, D-AP5, $50 \mu \mathrm{M}$ respectively) were applied to isolate AMPA receptor (AMPAR)-mediated EPSCs. We applied the selective $5-\mathrm{HT}_{1 \mathrm{~B}} \mathrm{R}$ agonist CP93129 during whole-cell recordings, and the EPSCs were inhibited in a dosedependent manner (Fig. 1b, CP93129; 50 nM inhibited to $55 \pm 4 \% n=13 ; 400 \mathrm{nM}$ to $37 \pm 3 \% p<0.01, n=14$; all significant $p<$ $0.01)$. The $\mathrm{GABA}_{\mathrm{B}} \mathrm{R}$ agonist, baclofen, similarly inhibited EPSCs profoundly (Fig. $1 c ; 1$ $\mu \mathrm{M}$ to $48 \pm 9 \% n=7 ; 10 \mu \mathrm{M}$ to $9 \pm 2 \% n=$ 5 ; $100 \mu \mathrm{M}$ to $7 \pm 3 \%$; all results significant, $p<0.01$ ). Baclofen and CP93129 each inhibited synaptic transmission in every recording.

Further supporting a conclusion that $5-\mathrm{HT}_{1 \mathrm{~B}} \mathrm{Rs}$ and $\mathrm{GABA}_{\mathrm{B}} \mathrm{Rs}$ are functionally colocalized to the same terminals, the combination of intermediate concentrations of baclofen and addition of CP93129 did not cause a linearly additive inhibition of responses. Instead, responses remaining in baclofen $(1 \mu \mathrm{M})$ were inhibited by CP93129 (400 nM) significantly less effectively than in control (in $1 \mu \mathrm{M}$ baclofen, 400 nM CP93129 reduced the response to $67 \pm 9 \%$ of the response in baclofen; significantly less than the effect of CP93129 against control, $p<0.05$; Fig. $1 d, e ; n=7$ ) This limited capacity to sum inhibitory effects indicates a convergence of targets; specifically that both receptors exist on the same presynaptic terminals. To confirm this, a further three experiments were performed in which a saturating dose of baclofen $(10 \mu \mathrm{M})$ was applied to inhibit an evoked EPSC, baclofen was washed from
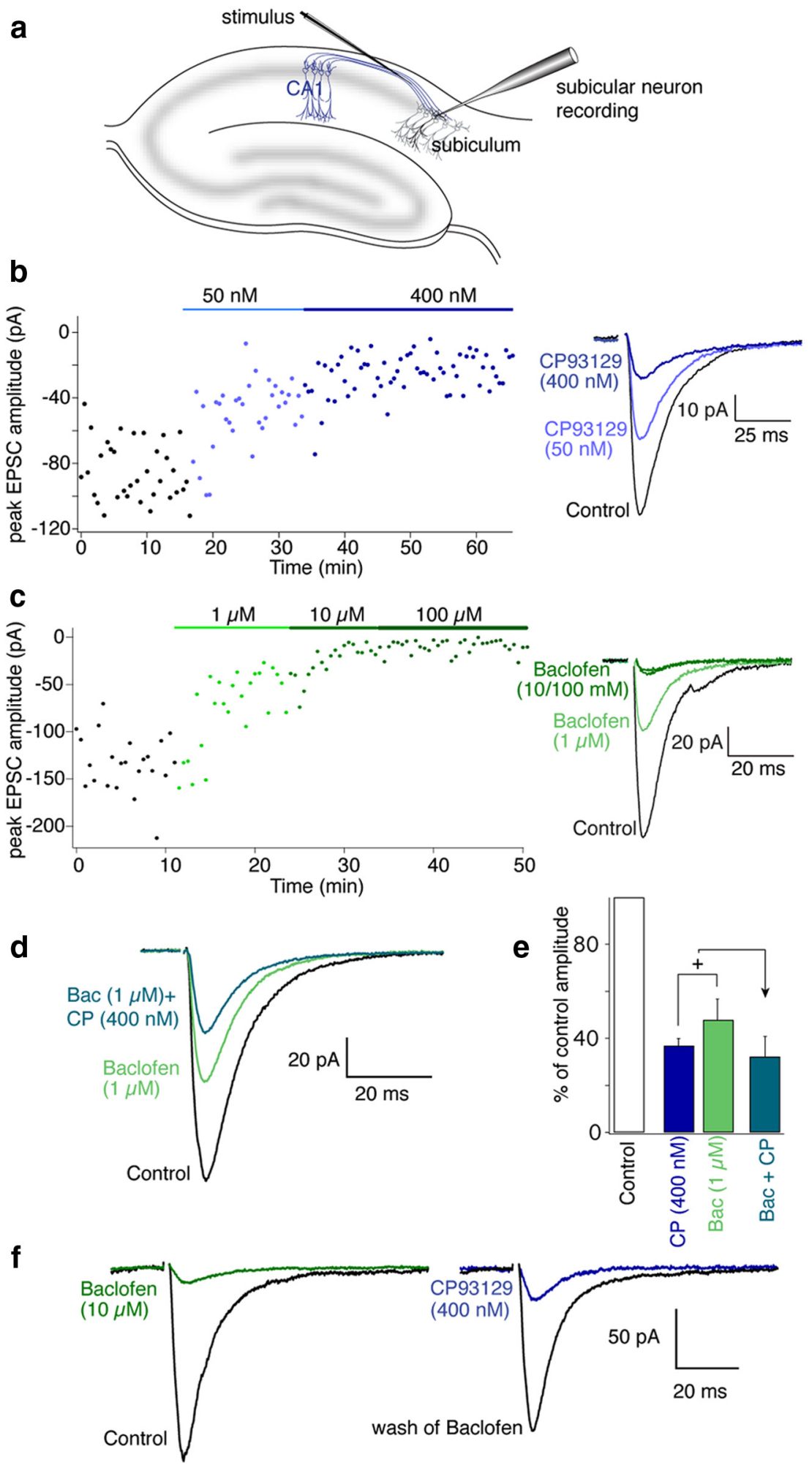

Figure 1. $5-\mathrm{HT}_{1 \mathrm{~B}}$ and $\mathrm{GABA}_{\mathrm{B}}$ receptors inhibit synaptic transmission at $\mathrm{CA} 1$-subicular synapses. $\boldsymbol{a}$, CA1 pyramidal axons were stimulated close to the CA1- subiculum boundary with a glass-coated tungsten microelectrode. Subicular pyramidal neurons were recorded in whole-cell voltage-clamp mode. $\boldsymbol{b}$, Plot of peak EPSC amplitude with time in Control (black), 50 nм CP93129 (light blue), and $400 \mathrm{~nm}$ (P93129 dark blue (stimuli at 30 s intervals). Right inset, Means of last 10 EPSCs in each condition from graph. $c$, Plot of peak EPSC amplitude in Control (black) baclofen $(1,10$, and $100 \mu \mathrm{m}$; green). Right inset, Means of last 10 EPSCs in each condition. $\boldsymbol{d}$, Means of 10 EPSCs in Control (black), baclofen ( $1 \mu \mathrm{M}$; green), and baclofen (1 $\mu \mathrm{M}$ ) plus (P93129 (400 nм, blue/green). e, Histogram comparing mean inhibition by (P93129 and baclofen against the same doses combined indicating convergence of the receptor targets on the same synapses. $f$, Means of 10 EPSCs (left

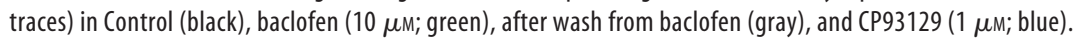



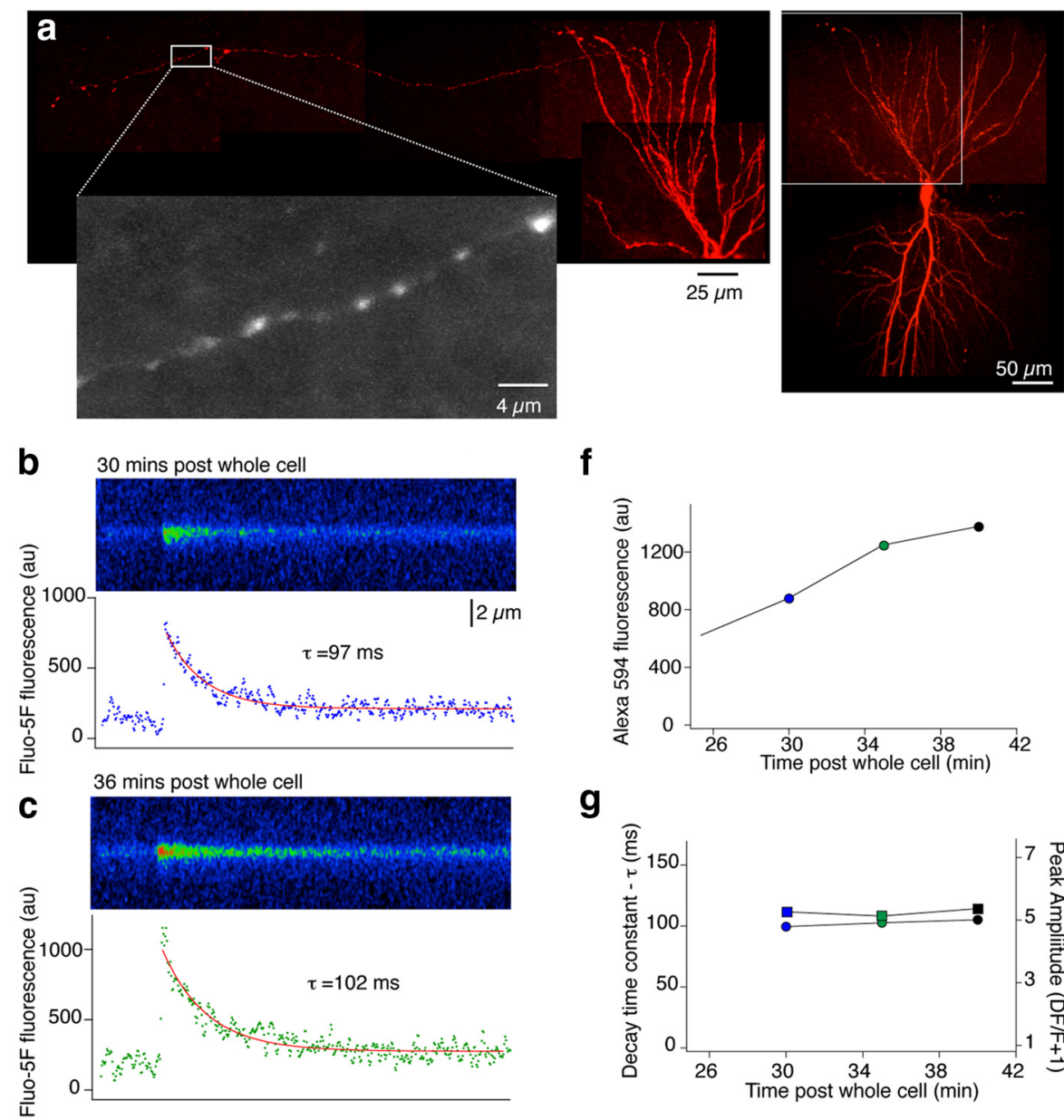

g
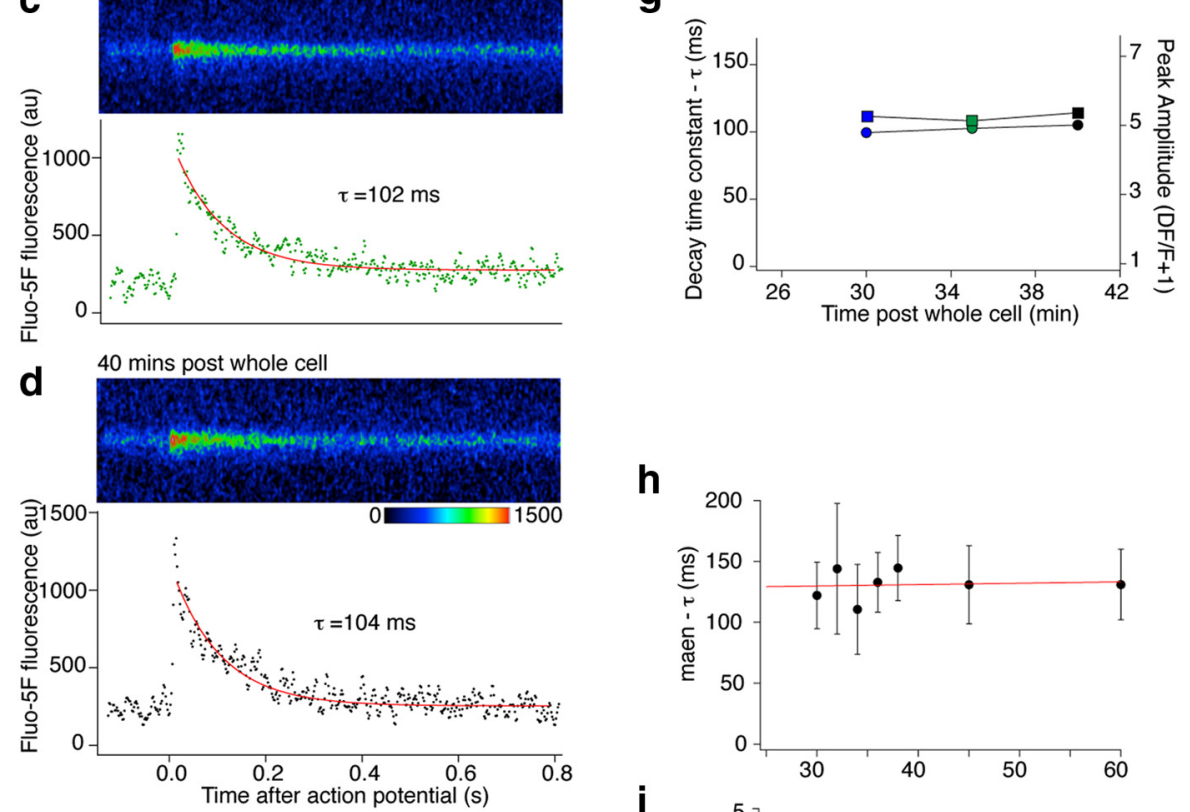

h
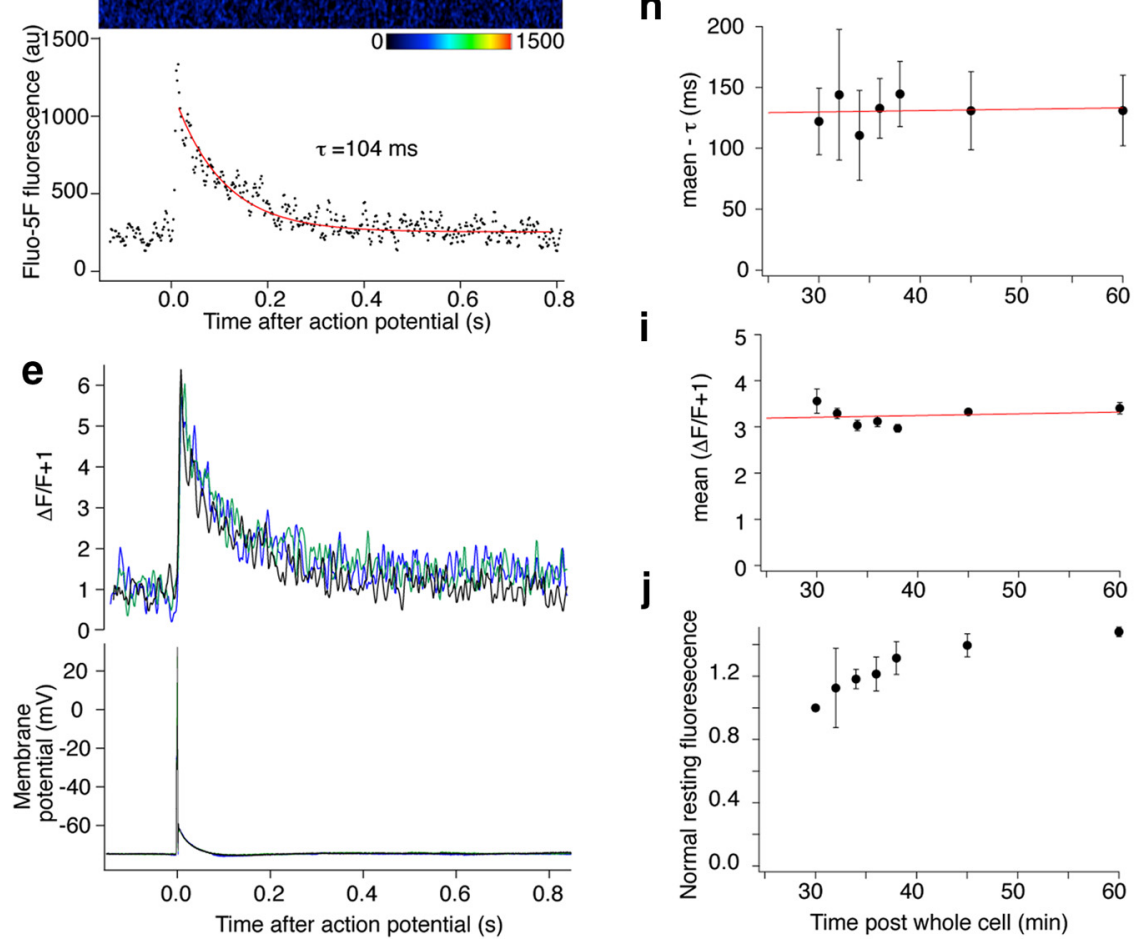

i

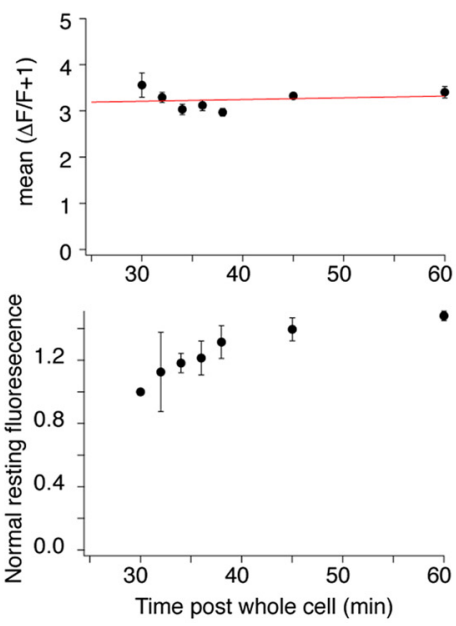

Figure 2. $\mathrm{Ca}^{2+}$ transients are reliably recorded in CA1 pyramidal neuron presynaptic terminals within the subiculum following labeling from a whole-cell electrode on the soma. $\boldsymbol{a}$, Composite image of CA1 neuron reconstructed from 3D stacks obtained by scanning confocally. The neuron was filled with dyes from the electrode: Alexa (250 $\mu \mathrm{M})$ to label the (Figure legend continues.) 
the superfusate, and a saturating dose of CP93129 (1 $\mu \mathrm{M})$ was applied (Fig. $1 f$ ). Baclofen inhibited the response to $11 \pm 5 \%$ of control; CP93129 subsequently inhibited the response to $24 \pm$ $8 \%$ of amplitude after wash of baclofen effects of both CP93129 and baclofen were significant $(p<0.01)$. Because both agonists can inhibit the response by $>50 \%$ these receptors must be present on the same presynaptic terminals.

\section{GPCR activation and presynaptic $\mathrm{Ca}^{2+}$ entry}

Modulators of presynaptic $\mathrm{Ca}^{2+}$ channels are key regulators of neurotransmission and GPCRs modulate presynaptic $\mathrm{Ca}^{2+}$ entry (Miller, 1998; Brown and Sihra, 2008). Therefore, we measured presynaptic $\mathrm{Ca}^{2+}$ transients in single presynaptic varicosities of CA1 neurons projecting to neurons in the subiculum, the main hippocampal output. To image single presynaptic varicosities, CA1 neurons were recorded in current clamp with patch electrodes containing Alexa 594 hydrazide (Alexa, $250 \mu \mathrm{M}$ ) and a low affinity $\mathrm{Ca}^{2+}$ indicator, Fluo-5F $(200 \mu \mathrm{M})$. After $\sim 30 \mathrm{~min}$ of dye diffusion, cells were imaged and axons tracked to the subiculum using the red fluorescent dye Alexa 594 (Fig. 2a). Single action potentials evoked by $2 \mathrm{~ms}$ depolarizing current pulses through the recording patch pipette caused presynaptic $\mathrm{Ca}^{2+}$ transients in axon varicosities, which were line scanned while confocally imaging Fluo-5F (Fig. $2 b-e$ ). To ensure that $\mathrm{Ca}^{2+}$ transients were unaffected by increasing dye/buffer concentration as it diffused into the axon, we recorded transients as the dye concentration increased. Values of baseline and peak increased (Fig. $2 b-d, f$ ) as the concentration of dye at the synapse increased (Fig. $2 f, j$ ), but signals expressed as $\Delta F / F$ remained constant with no change in peak amplitude of the response (Fig. $2 e, i$ ) or of decay rate (Fig. $2 e, h$ ), which is very sensitive to dye buffering capacity (Neher and Augustine, 1992; Jackson and Redman, 2003). Thus, at $200 \mu \mathrm{M}$, Fluo-5F buffering capacity is minimal compared with endogenous buffering and stably records action potential-induced presynaptic $\mathrm{Ca}^{2+}$ transients ( $n=6$ preparations).

After recording control $\mathrm{Ca}^{2+}$ transients, we applied a saturating dose of CP93129 ( $1 \mu \mathrm{M}$, which reduces synaptic responses to $<25 \%$ of control amplitudes), and imaged single action potential-evoked presynaptic $\mathrm{Ca}^{2+}$ transients as above. CP93129 altered neither $\mathrm{Ca}^{2+}$ entry (mean transient in CP93129 was $96 \pm$ $7 \%$ of control; Fig. $3 a-d ; n=6$ ) nor electrophysiological properties of the neuron. Indeed, because we resolved individual $\mathrm{Ca}^{2+}$ responses to single action potentials in individual presynaptic terminals, it is clear that no modulation of presynaptic $\mathrm{Ca}^{2+}$ responses occurs and that no loss of action potential propagation was recorded. Sequences of individual response amplitudes from

\section{$\leftarrow$}

(Figure legend continued.) neuron (shown in red) and to trace axons to subiculum to identify presynaptic varicosities (expanded, grayscale) and Fluo-5F (200 $\mu \mathrm{m})$ for $\mathrm{Ca}^{2+}$ measurements. $\boldsymbol{b}$, After identifying a presynaptic varicosity the neuron was stimulated with single action potentials and individual $\mathrm{Ca}^{2+}$ transient responses were obtained by line scanning one terminal varicosity. No responses could be recorded from axons between the varicosities. Responses were recorded over time as the dye concentration rose by diffusion into the presynaptic varicosities (c, d). The integrated signals were calculated from these regions (graphs below line scan images). Peak values of signal intensity and rate of response decay were obtained from single exponential fits to these data. $\boldsymbol{e}$, The data in $\boldsymbol{b}-\boldsymbol{d}$ were expressed as $(\Delta F / F+1)$ and overlaid. Colors from $\boldsymbol{b}$-d. $\boldsymbol{f}$, Graph demonstrating rise in intensity of Alexa 594 in this neuron's terminal over the time course of the experiment as the dye diffused into the terminal varicosities. $\boldsymbol{g}$, Graph of decay rate $(\tau$, left axis) and peak value of $(\Delta F / F+1)$ for this presynaptic varicosity during the experiment. $\boldsymbol{h}$, Mean decay rate $(\tau)$ and $(\boldsymbol{i})$ the mean peak $(\Delta F / F+1)$ during the course of the experiments ( $n=6$ preparations). $\boldsymbol{j}$, Graph showing rise in intensity of Alexa 594 signal normalized to the first time point of recording in all terminals (same 6 preparations as $\boldsymbol{h}$ and $\boldsymbol{i}$ ). six neurons are shown (Fig. 3d) with no change in variance after CP93129 application (mean variances before and after CP93129 were $0.037 \pm 0.012$ and $\left.0.038 \pm 0.013(\Delta F / F)^{2}\right)$.

We performed similar experiments with the $\mathrm{GABA}_{\mathrm{B}} \mathrm{R}$ agonist baclofen (Fig. $3 e-h)$. Baclofen slightly hyperpolarized the neuron (Fig. $3 g$ ), however, stimuli always resulted in action potentials. Baclofen inhibited presynaptic $\mathrm{Ca}^{2+}$ transients (to $56 \pm 7 \%$ of control, $p<0.05$; Fig. $3 e, f ; n=7)$. Each of the $\mathrm{Ca}^{2+}$ transient events were recorded from one action potential in one presynaptic terminal, thus we can be certain that the $\mathrm{Ca}^{2+}$ inhibition recorded was not due to action potential failure in a subset of axons, because each action potential evoked a corresponding presynaptic $\mathrm{Ca}^{2+}$ transient. Indeed, in baclofen, no failure of presynaptic $\mathrm{Ca}^{2+}$ transients was recorded; rather we recorded a reduction in amplitude of each evoked response (Fig. $3 h$ ). While both baclofen and CP93129 inhibit exocytosis at this synapse, baclofen inhibits presynaptic $\mathrm{Ca}^{2+}$ entry, whereas CP93129 does not.

\section{The presynaptic target of $5-\mathrm{HT}_{1 \mathrm{~B}}$ receptors: spontaneous release}

Inhibition of presynaptic $\mathrm{Ca}^{2+}$ entry by baclofen adequately explains its presynaptic inhibition should a fourth power relationship couple $\mathrm{Ca}^{2+}$ entry to neurotransmitter release (Dodge and Rahamimoff, 1967). Thus, if we take the fourth power of each of the $\mathrm{Ca}^{2+}$ signals after baclofen $(10 \mu \mathrm{M})$ these would predict a reduction of the EPSC to $15 \pm 7 \%$ of control. This is not significantly different from the observed reduction of the EPSC amplitude recorded in baclofen ( $9 \pm 2 \%$ of control; $10 \mu \mathrm{M}$; Fig. 1 ).

In contrast, $5-\mathrm{HT}_{1 \mathrm{~B}} \mathrm{Rs}$ must inhibit neurotransmitter release by another mechanism. The equivalent fourth power of the $\mathrm{Ca}^{2+}$ signal caused by CP93129 was to just $93 \pm 20 \%$ of control (significantly different from the effect on synaptic transmission; $p<$ $0.05)$. Thus, $5-\mathrm{HT}_{1 \mathrm{~B}} \mathrm{Rs}$ must inhibit release by a mechanism that does not cause a reduction in presynaptic $\mathrm{Ca}^{2+}$ entry. One such mechanism was first identified at the neuromuscular junction, where adenosine inhibits $\mathrm{ACh}$ release by a $\mathrm{Ca}^{2+}$-independent mechanism that leads also to significant reductions in spontaneous neurotransmitter release (Silinsky, 1984, 2008). Thus, we tested whether $5-\mathrm{HT}_{1 \mathrm{~B}} \mathrm{Rs}$ inhibit spontaneous release. mEPSCs were recorded in subicular neurons in tetrodotoxin (TTX; $1 \mu \mathrm{M}$ ) to prevent evoked release, and D-AP5 (50 $\mu \mathrm{M})$ and bicuculline ( 5 $\mu \mathrm{M})$ to isolate AMPAR-mediated EPSCs before and during application of CP93129 (400 nM; $n=6$; Fig. $4 a-d$ ). Events were detected as indicated (see Materials and Methods) and showed a very similar kinetic profile to evoked events (Fig. 4e). The mean amplitudes and kinetic profiles of these events were compared before and during application of CP93129 (400 nM). CP93129 had no effect on amplitude (mean mEPSC amplitude in CP93129 was $99 \pm 6 \%$ of control) or kinetic profile of the events (Fig. $4 f$ ), demonstrating that the effect of agonist was not postsynaptic. Furthermore, the amplitude distribution and cumulative amplitude distributions (Fig. 4g) before and in CP93129 were identical. Similarly the agonist had no effect on the frequency distribution or cumulative frequency distribution of the recorded events (frequency of events in CP93129 was $116 \pm 21 \%$ of control; Fig. $4 h$, significance of distributions was tested with two-sample Kolmogorov-Smirnov tests). Thus, in contrast to neuromuscular effects of adenosine (Silinsky, 1984), $5-\mathrm{HT}_{1 \mathrm{~B}} \mathrm{Rs}$ do not affect mEPSCs.

The lack of effect of $5-\mathrm{HT}_{1 \mathrm{~B}} \mathrm{R}$ activation on spontaneous release is consistent with an inhibitory effect targeting an aspect of $\mathrm{Ca}^{2+}$-evoked exocytosis. As a comparison similar experiments 


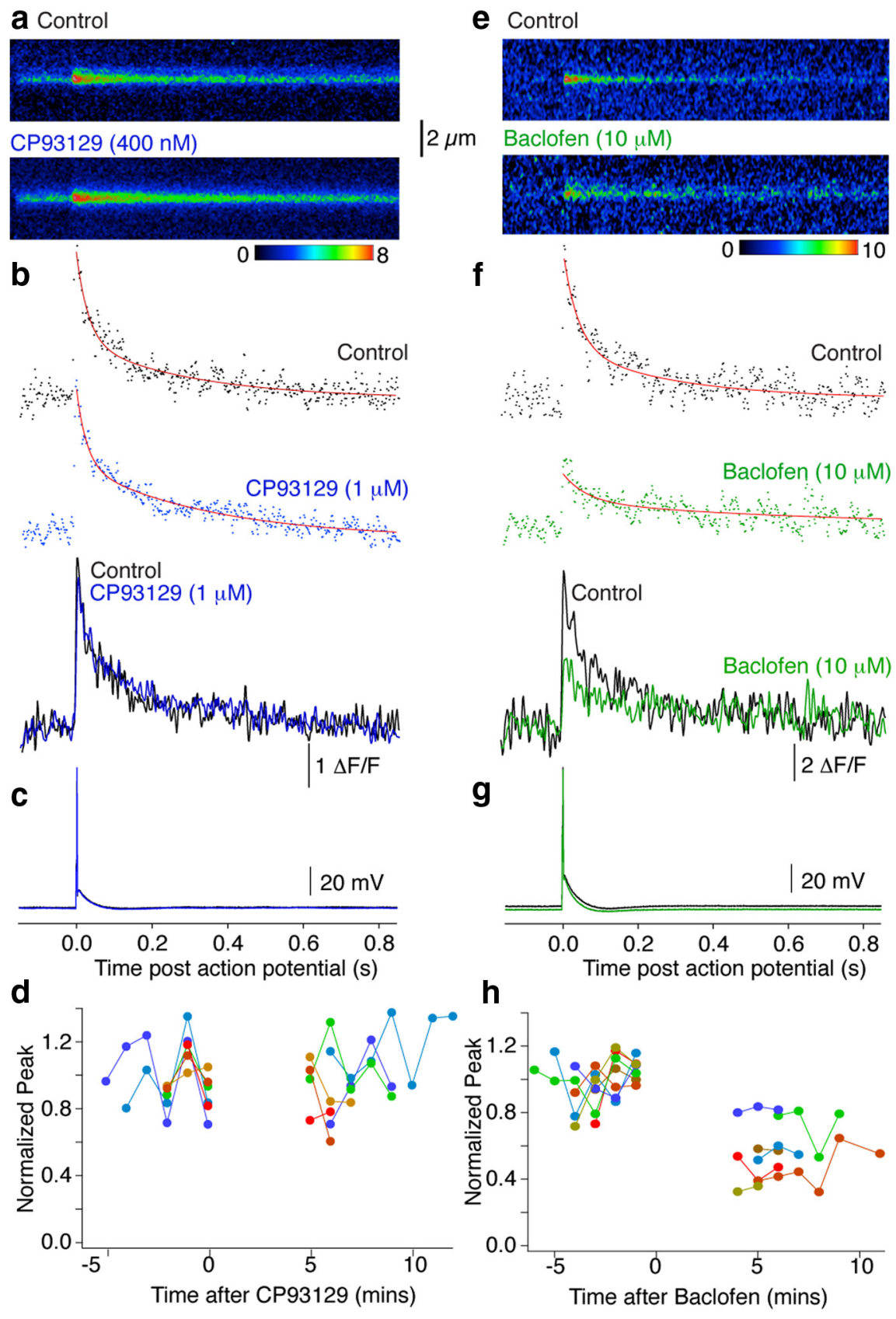

Figure 3. Differential inhibition of $\mathrm{Ca}^{2+}$ transients by $5-\mathrm{HT}_{1 \mathrm{~B}} \mathrm{Rs}$ and $\mathrm{GABA}_{\mathrm{B}} \mathrm{Rs}$. $\boldsymbol{a}$, Line scans (as in Fig. 2) from individual varicosities in the subiculum to resolve action potential-evoked $(\boldsymbol{c})$ presynaptic $\mathrm{Ca}^{2+}$ transients (mean 3 responses in Control and 3 in (P93129; $1 \mu \mathrm{M}) . \boldsymbol{b}$, Signals were integrated for the sweeps over the terminal varicosities and amplitudes expressed as $\Delta F / F$ (Control, black; in (P93129, blue). Peak amplitudes were calculated from double exponential fits ( $\boldsymbol{b}$, red). Traces overlaid (below) show no effect of (P93129 application (time base identical, $\boldsymbol{a}-\boldsymbol{c}$ ). $\boldsymbol{d}$, Peak amplitudes normalized to the mean Control amplitude before drug application were plotted against time for all cells. Each data point is the response to a single action potential in a single terminal varicosity. Colors represent results from individual terminals $(n=6) . \boldsymbol{e}-\boldsymbol{g}$, In another neuron baclofen $(10 \mu \mathrm{m})$ imaged and stimulated under the same conditions as above significantly reduced $\mathrm{Ca}^{2+}$ transient amplitudes. $\boldsymbol{h}$, Amplitudes of individual action potential-evoked $\mathrm{Ca}^{2+}$ transients demonstrate that in all seven neurons, although individual responses were reduced in amplitude in baclofen, failure of responses never occurred.

were performed on spontaneous release during the application of baclofen. Spontaneous mEPSCs were again recorded in subicular neurons in TTX $(1 \mu \mathrm{M})$, D-AP5 $(50 \mu \mathrm{M})$, and bicuculline (5 $\mu \mathrm{M})$ to isolate AMPAR-mediated EPSCs before and during application of baclofen (10 $\mu \mathrm{M} ; n=5$; Fig. $4 i-l)$. The mean amplitudes and kinetic profiles of these events were compared before and during application of baclofen, which had no effect on amplitude (mean mEPSC amplitude in baclofen was $106 \pm 17 \%$ of control) or kinetic profile of the events (Fig. $4 \mathrm{~m}$ ) or on the amplitude distribution and cumulative amplitude distributions (Fig. 4n). Similarly baclofen had no effect on the frequency distribution or cumulative frequency distribution of the recorded events (frequency of events in baclofen was $94 \pm 22 \%$ of control; Fig. $4 o$; significance of distributions were tested with two-sample Kolmogorov-Smirnov tests). Thus, neither $\mathrm{GABA}_{\mathrm{B}} \mathrm{Rs}$ nor $5-\mathrm{HT}_{1 \mathrm{~B}} \mathrm{Rs}$ modify spontaneous release, which occurs independently of $\mathrm{Ca}^{2+}$-entry through $\mathrm{Ca}^{2+}$ channels and is likely activated by Doc2 rather than synaptotagmin I (Groffen et al., 2010; Pang et al., 2011).

The presynaptic target of $5-\mathrm{HT}_{1 \mathrm{~B}}$ receptors: asynchronous release Baclofen may clearly inhibit neurotransmitter release by reducing presynaptic $\mathrm{Ca}^{2+}$ entry. However, CP93129 and $5-\mathrm{HT}_{1 \mathrm{~B}} \mathrm{Rs}$ do not modify presynaptic $\mathrm{Ca}^{2+}$ signals and yet only act on $\mathrm{Ca}^{2+}$. evoked release. A second such mechanism by which GPCRs inhibit neurotransmitter release with no inhibitory effect on presynaptic $\mathrm{Ca}^{2+}$ entry has been identified in lamprey synapses (Blackmer et al., 2001; Gerachshenko et al., 2005), in amygdala (Delaney et al., 2007), and in chromaffin cells (Blackmer et al., 2005). G $\beta \gamma$ inhibits release by a competitive interaction with synaptotagmin I at the C-terminal region of the SNARE complex (Yoon et al., 2007). Synaptotagmin binds $\mathrm{Ca}^{2+}$ to evoke vesicle fusion, and $\mathrm{Ca}^{2+}$-synaptotagmin I competes with $\mathrm{G} \beta \gamma$ at the C-terminal region of the SNARE complex in vitro, and in lamprey synapses (Blackmer et al., 2005; Gerachshenko et al., 2005; Yoon et al., 2007). Substitution of $\mathrm{Sr}^{2+}$ for $\mathrm{Ca}^{2+}$ in the superfusate provides an approach to identifying whether $\mathrm{G} \beta \gamma$ interacts with this $\mathrm{C}$-terminal region of the SNARE complex.

$\mathrm{Sr}^{2+}$ evokes asynchronous vesicle fusion following evoked entry through $\mathrm{Ca}^{2+}$ channels (Mellow et al., 1978) but does not cause synaptotagmin to interact with SNARE complexes (Shin et al., 2003; Bhalla et al., 2005). Given that $\mathrm{Sr}^{2+}$ enters through $\mathrm{Ca}^{2+}$ channels and yet does not cause synaptotagmin SNARE interactions, it provides an independent approach to determine whether GPCRs act at $\mathrm{Ca}^{2+}$ channels or via synaptotagmin I/SNARE complex interactions. Thus, we first determined whether $\mathrm{Sr}^{2+}$-synaptotagmin I competes with G $\beta \gamma$ at SNARE complexes using a sensitive quantitative in vitro fluorescence assay (Phillips and Cerione, 1991; Yoon et al., 2007). $G \beta_{1} \gamma_{1}$ (20 nM assay concentration) was labeled with an environmentally sensitive probe, MIANS, which shows enhanced fluorescence in more hydrophobic local conditions, indicating interaction with a binding partner. The assay was used to 

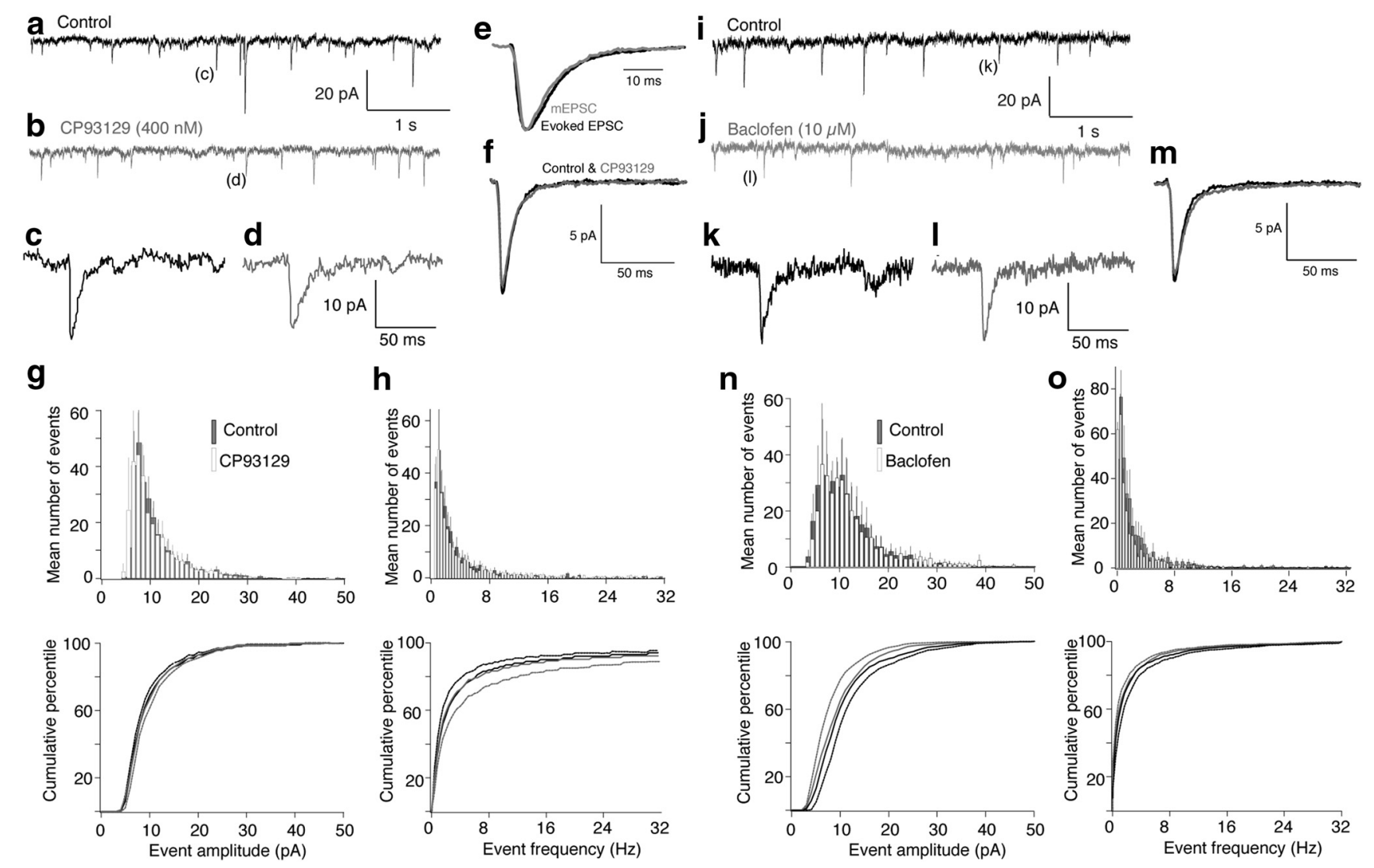

Figure 4. Neither $5-\mathrm{HT}_{1 \mathrm{~B}} \mathrm{Rs}$ nor $\mathrm{GABA}_{\mathrm{B}} \mathrm{Rs}$ alter spontaneous release in the subiculum. $\boldsymbol{a}$, Spontaneous events recorded in whole-cell voltage-clamped subicular pyramidal neurons. Recordings were in TTX, bicuculline and AP-5 to isolate AMPAR-mediated mEPSCs. $\boldsymbol{b}$, The 5-HT ${ }_{1 B}$ R agonist, CP93129 (400 nM), was applied. $\boldsymbol{c}, \boldsymbol{d}$, Examples of detected events in $\boldsymbol{a}$ and $\boldsymbol{b}$. $\boldsymbol{e}$, The kinetic profile of averaged detected mEPSCs (gray) was compared with evoked responses obtained before addition of TTX in the same neurons (black). Events were scaled the same arbitrary amplitudes. $f$, Means of mEPSCs detected in Control (black) and in CP93129 (gray). The agonist altered neither amplitude nor kinetic profile. $\boldsymbol{g}$, Mean event amplitude histograms were plotted for all cells examined before (gray) and after CP93129 (white). Bars indicate SEMs obtained comparing across preparations ( $n=5)$. Cumulative histograms are plotted below (Control, black; CP93129, gray). SEMs represented as Control (black dashed line above curves) and in (P93129 (gray dashed line below curve). $\boldsymbol{h}$, Event frequency distribution curves for the same datasets as $\boldsymbol{g}$. Grayscale and SEMs marked in the same way. $\boldsymbol{i}$, Spontaneous events were recorded as in $\boldsymbol{a}$. $\boldsymbol{j}$, The GABA R agonist, baclofen $(1 \mu \mathrm{M})$, was applied. $\boldsymbol{k}, \boldsymbol{l}$, Examples of detected events in $\boldsymbol{i}$ and $\boldsymbol{j}$. $\boldsymbol{m}$, Means of $\mathrm{mEPSCs}$ detected in Control (black) and in baclofen (gray). The agonist altered neither amplitude nor kinetic profile. $\boldsymbol{n}$, Mean event amplitude histograms were plotted in Control and baclofen (10 $\mu \mathrm{m}$ ) as for $\boldsymbol{g} . \mathbf{0}$, Event frequency distribution histograms for the same datasets as in $\boldsymbol{n}$.

quantify synaptotagmin I C2AB fragment competition with MIANS-labeled G $\beta \gamma$ for binding to t-SNARE complexes comprising the syntaxin1A H3 domain and SNAP-25 in increasing concentrations of either $\mathrm{Sr}^{2+}$ or $\mathrm{Ca}^{2+}$. We used a synaptotagmin I mutant (K326A, K327A) that exhibits wild-type SNARE binding affinity but which has a reduced propensity to oligomerize (Bai et al., 2004). MIANS-G $\beta \gamma$ fluorescence increases following interaction with t-SNARE complexes, but this increase is significantly reduced by $20 \mathrm{~nm}$ synaptotagmin I when applied in the presence of $\mathrm{Ca}^{2+}$ (Yoon et al., 2007). As a control, MIANS-G $\beta \gamma$ does not show significant interactions with $\mathrm{C} 2 \mathrm{AB}$ alone. Thus, we tested competition between G $\beta \gamma$ and C2AB at t-SNARE complexes substituting $\mathrm{Sr}^{2+}$ for $\mathrm{Ca}^{2+}$. The interaction between $20 \mathrm{nM}$ MIANS-G $\beta \gamma$ and $1 \mu \mathrm{m} \mathrm{t-SNARE} \mathrm{complex} \mathrm{was} \mathrm{only} \mathrm{slightly} \mathrm{re-}$ duced by $20 \mathrm{~nm} C 2 \mathrm{AB}$ in increasing $\mathrm{Sr}^{2+}$ concentrations up to $250 \mu \mathrm{M}$ (Fig. 5a; normalized fluorescence reduced to $69.8 \pm 4.0 \%$ of the response in $0 \mathrm{Sr}^{2+}$ ). To confirm earlier results, the experiment was repeated with $\mathrm{Ca}^{2+}$ and the effect with $\mathrm{Sr}^{2+}$ was substantially and significantly less than that seen for $250 \mu \mathrm{M} \mathrm{Ca}^{2+}$ (Fig. $5 b$; normalized fluorescence reduced to $5.8 \pm 8.9 \%$ of response in 0 $\mathrm{Ca}^{2+}, p<0.01$ compared with effect of $\mathrm{Sr}^{2+}$ ).

Thus, unlike $\mathrm{Ca}^{2+}$-synaptotagmin, $\mathrm{Sr}^{2+}$-synaptotagmin does not compete with $\mathrm{G} \beta \gamma$ to inhibit fusion, and while $\mathrm{Sr}^{2+}$ entry to the neuron will be modified by GPCRs acting at $\mathrm{Ca}^{2+}$ channels,
G $\beta \gamma$ targeting the SNARE complex cannot modify the effects of $\mathrm{Sr}^{2+}$ because there is no subsequent competition between $\mathrm{G} \beta \gamma$ and $\mathrm{Sr}^{2+}$-synaptotagmin at the SNARE complex Figure 5a). During recordings from subicular neurons in hippocampal slices, we replaced extracellular $\mathrm{Ca}^{2+}$ with $\mathrm{Sr}^{2+}$. Synchronous EPSCs (stimulated as Fig. 1) were reduced in amplitude while asynchronous events typical of $\mathrm{Sr}^{2+}$ (Mellow et al., 1982) were recorded (Fig. $5 c, d$ ). Asynchronous events were detected from $20 \mathrm{~ms}$ poststimulus to the end of the sweep (Fig. $5 c, d$, shading; 40 control sweeps, 40 CP93129 sweeps). Time/frequency histograms of mean frequencies of events for all neurons revealed the event frequency distribution. CP93129 had no effect on this distribution nor on overall event frequency (frequency in CP93129, was $97 \pm 5 \%$ at $50 \mathrm{~nm}$ and $88 \pm 12 \%$ at $400 \mathrm{~nm}$ events in $\mathrm{Sr}^{2+}$ alone; Fig. $5 d ; n=7$ ). Averaging detected events revealed that neither amplitudes nor kinetics of $\mathrm{Sr}^{2+}$-evoked asynchronous events were affected by CP93129 (Fig. $5 d$, inset).

Baclofen substantially reduces presynaptic $\mathrm{Ca}^{2+}$ entry to CA1 neuron terminals in the subiculum. Consequently, it may be used as a positive control to demonstrate the effect of inhibiting $\mathrm{Ca}^{2+}$ channels on $\mathrm{Sr}^{2+}$-evoked asynchronous events, because if $\mathrm{Ca}^{2+}$ channels are inhibited their permeation by $\mathrm{Sr}^{2+}$ will be correspondingly reduced. In contrast to CP93129, baclofen (1 $\mu \mathrm{M})$ substantially reduced $\mathrm{Sr}^{2+}$-evoked event frequencies (to $47 \pm$ 
a

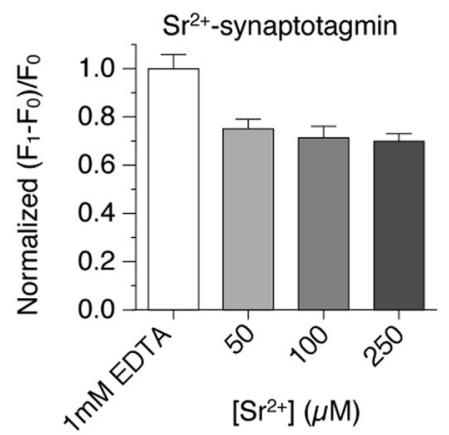

C
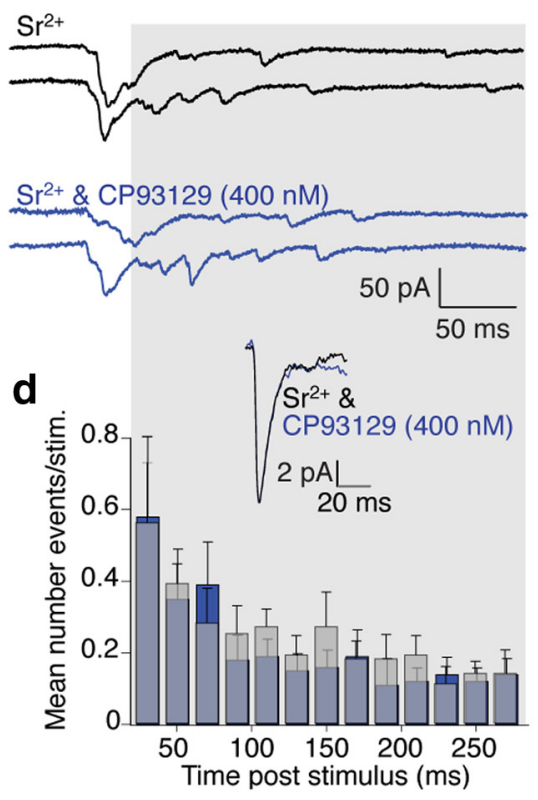

g

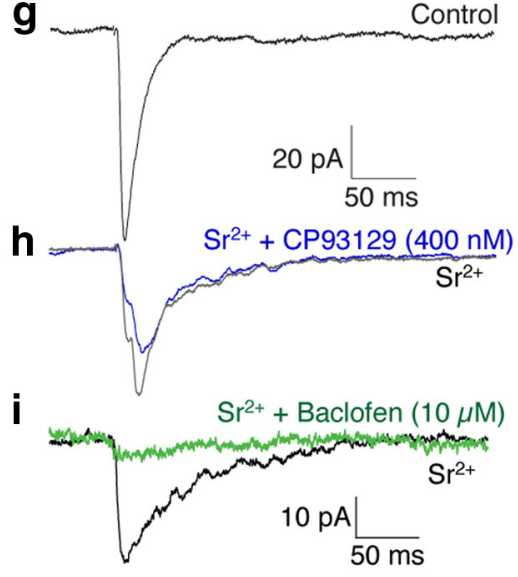

b

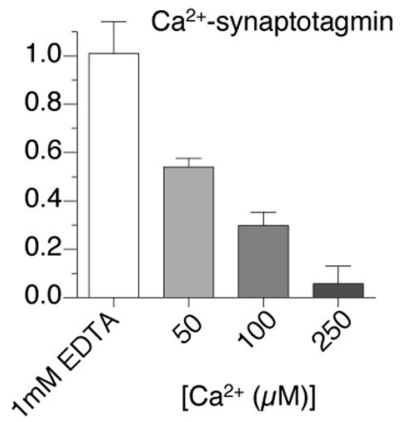

e

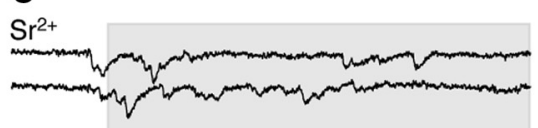

$\mathrm{Sr}^{2+}$ \& Baclofen $(1 \mu \mathrm{M})$
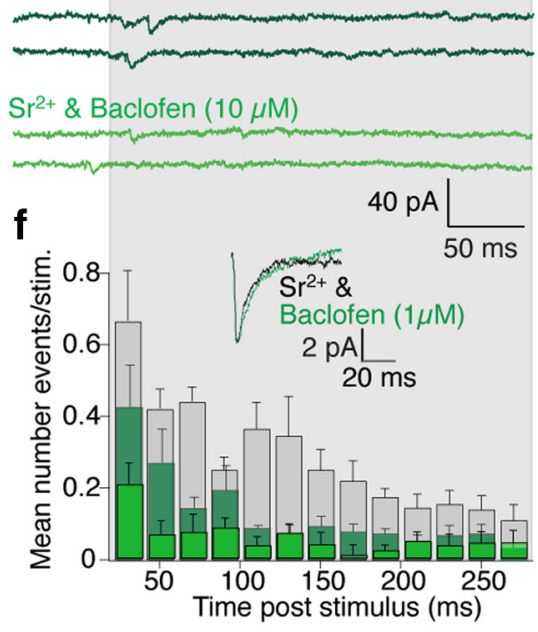

\section{j}



Figure 5. $\mathrm{GABA}_{\mathrm{B}} \mathrm{Rs}$ but not $5-\mathrm{HT}_{1 \mathrm{~B}} \mathrm{Rs}$ inhibit $\mathrm{Sr}^{2+}$-evoked neurotransmission. $\boldsymbol{a}$, Graphs of normalized fluorescence of MIANS-labeled $\mathrm{G} \beta \gamma$ bound to t-SNARE complexes in vitro. Synaptotagmin I in increasing $\left[\mathrm{Sr}^{2+}\right.$ ] slightly reduces $\mathrm{G} \beta \gamma$ binding to t-SNAREs. Binding of 1 $\mu \mathrm{m}$ t-SNARE to $20 \mathrm{~nm}$ MAINS-G $\beta \gamma$ was measured by fluorescence enhancement. $\boldsymbol{b}$, In contrast, synaptotagmin I in $\mathrm{Ca}^{2+}$ substantially reduced fluorescence $\left[\mathrm{Ca}^{2+}\right]$ dependently. c, Examples of $\mathrm{Sr}^{2+}$-evoked EPSCs in subicular pyramidal neurons and in CP93129 (400 nм; blue) following stimulation of CA1 pyramidal neuron axons. $d$, Frequency distribution from gray region across traces in $c$; mean number of events/stimulus from all neurons of 40 stimuli in each neuron in $\mathrm{Sr}^{2+}$ and in $\mathrm{Sr}^{2+}$ plus (P93129 (blue). Inset shows mean of detected asynchronous events in Control and in CP93129 showing no effect on detected event amplitudes or kinetic profiles.e, $\mathrm{Sr}^{2+}$-evoked EPSCS in another cell (Control, black) and in baclofen ( $1 \mu \mathrm{m}$; dark green and $10 \mu \mathrm{m}$; green).f, Frequency distribution from gray region across traces in e plotted in Control (black) and baclofen ( $1 \mu \mathrm{m}$; dark green and $10 \mu \mathrm{m}$; green). Data are from all examined neurons. Inset shows mean of detected asynchronous events in Control and in baclofen showing no effect on detected event amplitudes or kinetic profiles even as the frequency of events was reduced. $\boldsymbol{g}$, Mean of EPSCs in $\mathrm{Ca}^{2+}(\mathrm{Control}) \cdot \boldsymbol{h}, \mathrm{Sr}^{2+}$ (gray), $\mathrm{Sr}^{2+}+\mathrm{CP93129}$ (blue; $\left.400 \mathrm{~nm}\right) . \boldsymbol{i}$, Mean of EPSCs in $\mathrm{Sr}^{2+}$ (black) and $\mathrm{Sr}^{2+}+$ baclofen (10 $\mu \mathrm{m}$; green).j, Summary of CP93129 effects ( $50 \mathrm{~nm} ; n=3$ and $\left.400 \mathrm{~nm} ; n=4\right)$ and baclofen ( $1 \mu \mathrm{m}$; $n=5$ and $10 \mu \mathrm{m} ; n=4)$ against frequencies and peak amplitudes in $\mathrm{Sr}^{2+}$.

$6 \%, n=5)$ and nearly eliminated them at a higher concentration (10 $\mu \mathrm{M}$; Fig. $5 e, f ;$ to $21 \pm 12 \%, n=4)$, but had no effect on kinetics (Fig. 5f, inset) or the mean amplitude of asynchronous events that were detected (Fig. $5 f$, inset).

Contrasting inhibitions by baclofen and $\mathrm{CP} 93129$ on $\mathrm{Sr}^{2+}$-evoked release are most notable on asynchronous events. Even so, CP93129-mediated inhibition of the early EPSC in $\mathrm{Sr}^{2+}$ was substantially less than in $\mathrm{Ca}^{2+}$ (EPSC was $92 \pm 2 \%$ of peak in $\mathrm{Sr}^{2+}$ at $50 \mathrm{~nm} \mathrm{CP93129} \mathrm{and} 67 \pm$ $7 \%$ at $400 \mathrm{~nm}$; Fig. $5 h$; significantly less inhibition than in $\mathrm{Ca}^{2+}, p<0.01$; reductions to 55 and $37 \%$ ). In contrast to CP93129, inhibition by baclofen in $\mathrm{Sr}^{2+}$ was similar to that in $\mathrm{Ca}^{2+}(1 \mu \mathrm{M}$ baclofen peak EPSC reduced to $53 \pm 3 \%$ of amplitude in $\mathrm{Sr}^{2+}$, in $10 \mu \mathrm{M}$ baclofen reduced to $18 \pm 3 \%, n=6$; Fig. $5 i$ ). Even the small inhibition by CP93129 may be explained by residual $\mathrm{Ca}^{2+}$ that cannot be removed (Xu-Friedman and Regehr, 1999).

Similarly to effects on event frequencies, neither amplitudes nor the distribution of $\mathrm{Sr}^{2+}$-evoked asynchronous events were affected by CP93129. This was shown to help clarify that no postsynaptic effects of these receptors account for the observed inhibition. As for event frequency data (Fig. 5), event amplitudes were plotted against time in a window from 20 to $300 \mathrm{~ms}$ after the stimulus (Fig. $6 a-d$; analysis of same data as Fig. 5; in all seven neurons mean event amplitude in $400 \mathrm{~nm}$ CP93129 was $108 \pm 5 \%$ of event amplitude in $\mathrm{Sr}^{2+}$ alone). Time/amplitude histograms and cumulative plots of mean event amplitudes for all neurons were plotted to show no effect on the amplitude distribution of events by CP93129.

Similar analysis was performed for neurons recorded in an intermediate baclofen dose $(1 \mu \mathrm{M})$, at which sufficient numbers of events were detected. Event amplitudes were plotted across a similar time window in $\mathrm{Sr}^{2+}$ and after addition of baclofen $(1 \mu \mathrm{M}$; Fig. $6 e, f)$. Time/amplitude histograms and cumulative plots of mean event amplitudes for all neurons showed no effect on the amplitude distribution of events by baclofen (Fig. $6 \mathrm{~g}, h$ ). The mean event amplitudes in baclofen $(1$ and $10 \mu \mathrm{M})$ were $93 \pm 3$ and $89 \pm 5 \%$, respectively, of the amplitudes in $\mathrm{Sr}^{2+}$ alone ( $n=5$ and 4, respectively). These data also indicate that neither agonist modified the postsynaptic response to detected events.

Spontaneous mEPSCs in $\mathrm{Ca}^{2+}$ containing Ringer (Fig. 4) were unaffected by $\mathrm{CP} 93129$ as were events in $\mathrm{Sr}^{2+}$. Furthermore, CP93129 was equally effective in in- 
hibiting evoked EPSCs in $\mathrm{Ca}^{2+}$ when the postsynaptic patch pipette contained GDP $\beta S$ to inactivate effects of postsynaptic GPCRs (data not shown). These results confirm that $5-\mathrm{HT}_{1 \mathrm{~B}} \mathrm{Rs}$ act presynaptically. Critically, the $\mathrm{Sr}^{2+}$ data confirms the $\mathrm{Ca}^{2+}$ imaging data demonstrating that $5-\mathrm{HT}_{1 \mathrm{~B}} \mathrm{Rs}$ do not modify presynaptic $\mathrm{Ca}^{2+}$ entry, but are instead consistent with 5-HT modifying synaptotagmin/SNARE complex interactions (Blackmer et al., 2001, 2005; Takahashi et al., 2001; Gerachshenko et al., 2005; Yoon et al., 2007) because $\mathrm{Sr}^{2+}$ synaptotagmin I does not interact with the SNARE complex (Fig. $5 a$ ) to cause exocytosis (Shin et al., 2003; Bhalla et al., 2005).

\section{The presynaptic target of 5- $\mathrm{HT}_{1 \mathrm{~B}}$ receptors: BoNT/A cleavage of C-terminal SNAP-25}

Because $\mathrm{Sr}^{2+}$ does not recruit synaptotagmin I to evoke release and $\mathrm{Sr}^{2+}$ synaptotagmin does not compete effectively with G $\beta \gamma$ at SNARE complexes, it is likely that $5-\mathrm{HT}_{1 \mathrm{~B}} \mathrm{Rs}$ modify fusion by targeting the SNARE complex C-terminal region. Consequently, we investigated how 5$\mathrm{HT}_{1 \mathrm{~B}} \mathrm{R}$ signal transduction interacts with this region of the SNARE complex. BoNT/A reduces presynaptic inhibition mediated by 5-HT via G $\beta \gamma$ in lamprey (Gerachshenko et al., 2005), noradrenaline in amygdala (Delaney et al., 2007), and G $\beta \gamma$ in PC12 cells (Blackmer et al., 2005). BoNT/A cleavage of the $\mathrm{C}$ terminus of SNAP-25 favors synaptotagmin I/SNARE interactions over those with $\mathrm{G} \beta \gamma$ (Yoon et al., 2007) without preventing SNARE complex formation. Thus, we determined the effects of BoNT/A on CP93129-mediated presynaptic inhibition.

Hippocampal slices were incubated (2-4 h) in light/heavy chain BoNT/A (1-2 $\mathrm{nM}$ ) to cleave the C-terminal 9 residues from SNAP-25. It remains unclear whether SNARE complex formation during priming might protect SNAP-25 from BoNT/A (Xu et al., 1998), thus, we eliminated any residual primed vesicles unaffected by BoNT/A during the incubation period. Subicular pyramidal neurons were recorded as in Figure 1 and stimuli were applied to CA1 axons.

Residual primed vesicles were eliminated by stimulation (400 stimuli, $1 \mathrm{~Hz}$; Fig. 7a). EPSCs were markedly depressed during the $1 \mathrm{~Hz}$ stimulation period, but partially recovered, albeit to a still significantly inhibited response ( $66.7 \pm 1 \%$ of control, $p<0.05, n=$ 5; Fig. 7a) when stimulation was slowed to $1 / 15 \mathrm{~Hz}$. CP93129 applied to these reduced responses caused much less inhibition, indicating that $5-\mathrm{HT}_{1 \mathrm{~B}} \mathrm{R}$ effectors target the SNARE complex (EPSC amplitudes were $77 \pm 5 \%$ of post $1 \mathrm{~Hz}$ amplitude; $n=5$, $50 \mathrm{nM}$, and $67 \pm 1 \%, 400 \mathrm{~nm} n=5$; Fig. 7a,b). This inhibition was significantly less than that seen in control recordings (Fig. 7e).

To ensure that the $1 \mathrm{~Hz}$ prestimulation did not compromise CP93129-mediated inhibition, slices were treated as con- trols without BoNT/A. Four hundred stimuli (1 Hz, applied as before) caused less short-term depression (Fig. 7c). EPSCs recovered to $82 \pm 1 \%$ of control at $1 / 15 \mathrm{~Hz}$ stimulation (Fig. $7 c, d)$. Subsequent application of CP9319 inhibited EPSCs to the same extent as it did in applications with no $1 \mathrm{~Hz}$ stimulation (for 50 and $400 \mathrm{~nm}$ to $46 \pm 4$ and $34 \pm 6 \%$ of post $1 \mathrm{~Hz}$ amplitudes; Fig. $7 c-e ; n=3$ ). Thus, $5-\mathrm{HT}_{1 \mathrm{~B}} \mathrm{R}$-mediated inhibition is curtailed following SNAP-25 cleavage with BoNT/A.

$5-\mathrm{HT}_{1 \mathrm{~B}} \mathrm{Rs}$ inhibit release to a much reduced extent after cleavage of the C-terminal 9 residues of SNAP-25 and the subsequent elimination of previously primed vesicles and their associated SNARE complexes. However, while most BoNTs cannot access their SNARE 

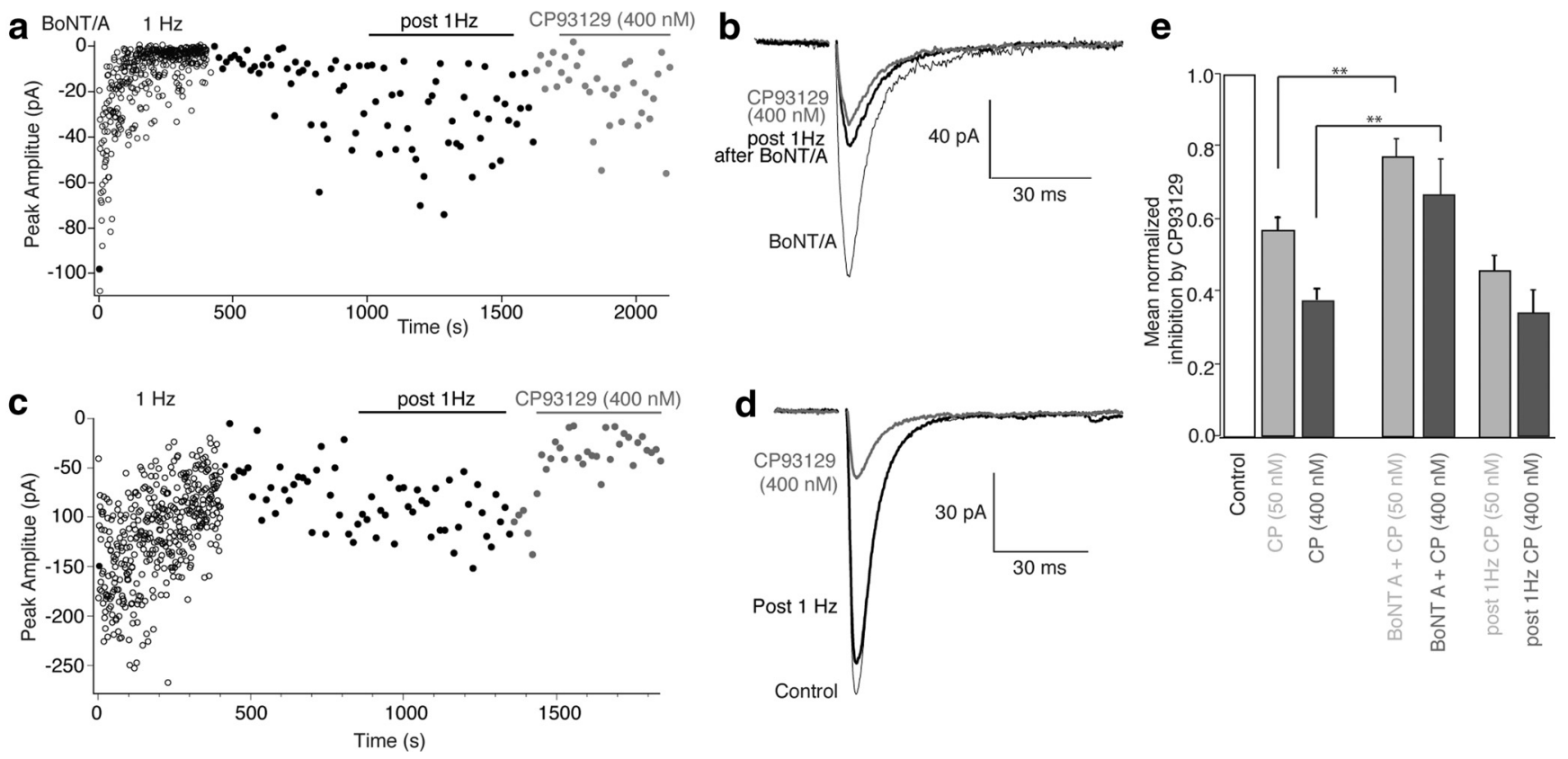

Figure 7. BoNT/A treatment substantially reduces $5-\mathrm{HT}_{1 \mathrm{~B}}$ receptor-mediated inhibition. $\boldsymbol{a}$, Graph of EPSC amplitudes recorded in subicular pyramidal neurons and stimulation of CA1 pyramidal neuron axons after BoNT/A pretreatment. Four hundred stimuli $(1 \mathrm{~Hz}$; open circles) eliminated pre-BoNT/A primed vesicles. Short-term depression from initial amplitude partially recovered at $1 / 15 \mathrm{~Hz}$ stimulation (filled circles). (P93129 (400 nM) was then applied (gray filled circles). $\boldsymbol{b}$, Mean of EPSCs before (black, thin line) and post $1 \mathrm{~Hz}$ stimulation (black) in CP93129 (gray) after BoNT/A treatment. c, EPSCs were recorded and evoked as in $\boldsymbol{a}$ and slices treated identically except BoNT/A toxin was not added to the media. Evoked EPSC amplitudes are graphed during $1 \mathrm{~Hz}$ stimulation for 400 stimuli $(\bigcirc)$. After a period of recovery at low frequency $(1 / 15 \mathrm{~Hz}$, black) CP93129 (gray) caused inhibition as in Control slices with no period of $1 \mathrm{~Hz}$ stimulation. $\boldsymbol{d}$, Means of EPSCs before $1 \mathrm{~Hz}$ stimulation (Control, thin black), after recovery from this stimulation (post $1 \mathrm{~Hz}$, black), and during (P93129 application (gray).e, Summary of (P93129 effects on EPSC amplitudes for all cells in Control, (50, $400 \mathrm{~nm} ; n=13,14)$, following BoNT/A, $1 \mathrm{~Hz}$ stimulation $(50,400 \mathrm{~nm}, n=5)$, and following $1 \mathrm{~Hz}$ stimulation with no prior BoNT/A treatment $(50,400 \mathrm{~nm}, n=3)$.
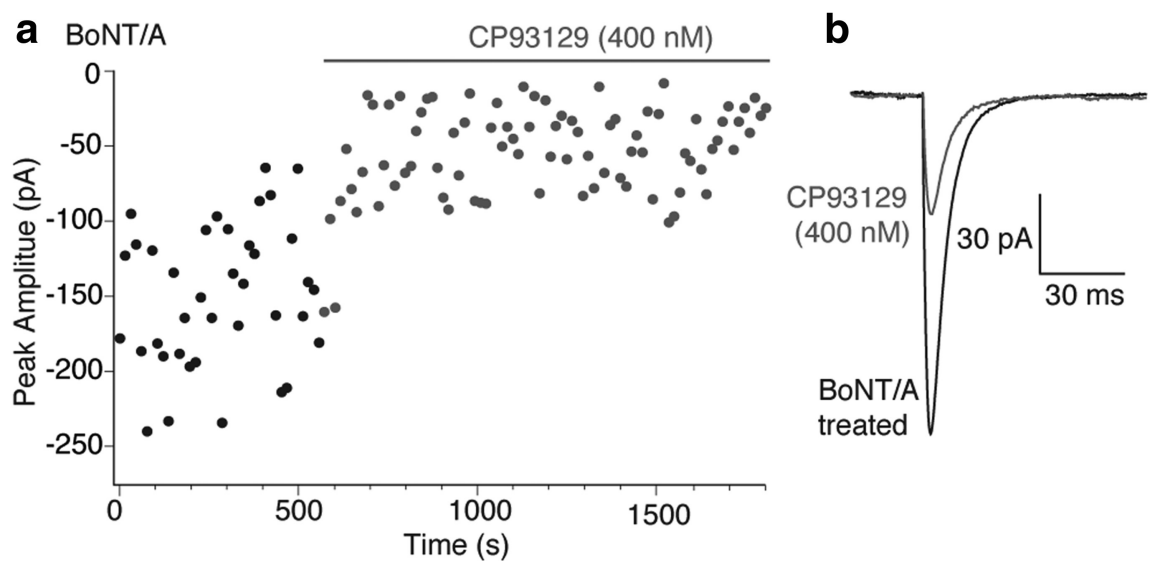

Figure 8. BoNT/A does not prevent effects of $5-\mathrm{HT}_{1 \mathrm{~B}}$ receptors on the previously primed vesicle pool. $\boldsymbol{a}$, In slices pretreated with BoNT/A toxin as for Figure 7, EPSCs were evoked as above but at $1 / 15 \mathrm{~Hz}$ for 35 stimuli with no period of $1 \mathrm{~Hz}$ stimulation. In these cells with no loss of preprimed vesicle pool, CP93129 inhibited EPSCs by similar amounts to Control responses. $\boldsymbol{b}$, Means of EPSCs after BoNT/A treatment (from $\boldsymbol{a}$ ) but before drug application (BoNT/A treated, black), and during (P93129 application (gray).

complex target proteins after the formation of ternary SNARE complexes during vesicle priming (Hayashi et al., 1994; Pellegrini et al., 1994), it is not clear whether this is true of BoNT/A. Indeed, following BoNT/A treatment, SNARE complexes can be formed, although with reduced efficacy at promoting vesicle fusion (Otto et al., 1995). It was possible to determine whether BoNT/A, like other BoNTs, fails to access primed vesicle SNAREs or whether BoNT/A treatment alone caused nonspecific damage to the synapses leading to a loss of $5-\mathrm{HT}_{1 \mathrm{~B}} \mathrm{R}$-mediated effects. Slices were treated with BoNT/A as for Figure 7. However, after BoNT/A treatment, no prestimulus train was given, thus leaving the primed vesicle pool intact before appli- cation of agonist. After obtaining controlevoked EPSCs at $15 \mathrm{~s}$ intervals, CP93129 reduced responses as for controls (to $29 \pm$ $3 \%$ at 400 nM; Fig. $8 a, b$ ). Thus, consistent with a final target of the $5-\mathrm{HT}_{1 \mathrm{~B}} \mathrm{R}$ on the primed vesicle (Gerachshenko et al., 2005), the readily releasable pool must be depleted after BoNT/A treatment in order for BoNT/A to prevent $5-\mathrm{HT}_{1 \mathrm{~B}} \mathrm{R}$-mediated inhibition.

From results using $\mathrm{Ca}^{2+}$ imaging, $\mathrm{Sr}^{2+}$ evoked asynchronous release, and BoNT/A it is clear that $5-\mathrm{HT}_{1 \mathrm{~B}} \mathrm{Rs}$ target the SNARE complex to modify $\mathrm{Ca}^{2+}$-synaptotagmin binding, while $\mathrm{GABA}_{\mathrm{B}}$ Rs inhibit presynaptic $\mathrm{Ca}^{2+}$ entry.

\section{Selective targeting of G $\boldsymbol{\beta} \gamma$ effector targets and the SNARE complex}

$\mathrm{GABA}_{\mathrm{B}} \mathrm{Rs}$ and $5-\mathrm{HT}_{1 \mathrm{~B}} \mathrm{Rs}$ are colocalized in the same synaptic pathway between CA1 and subicular pyramidal neurons but inhibit exocytosis by different mechanisms. These mechanisms nevertheless both use G $\beta \gamma$ subunits (Blackmer et al., 2001; Catterall and Few, 2008). $\mathrm{Ca}^{2+}$ channels may localize to the SNARE complex N terminus (Sheng et al., 1994, 1996), while 5- $\mathrm{HT}_{1 \mathrm{~B}} \mathrm{R}$-liberated $\mathrm{G} \beta \gamma$ interacts with the SNARE complex C terminus (Blackmer et al., 2001, 2005; Yoon et al., 2007). It is interesting that $5-\mathrm{HT}_{1 \mathrm{~B}} \mathrm{Rs}$ do not, under normal circumstances, modulate presynaptic $\mathrm{Ca}^{2+}$ while $\mathrm{GABA}_{\mathrm{B}}$ Rs do. We hypothesized that the SNARE complex separates receptor/effector complexes. To test this, we prevented SNARE complex 
formation by cleavage of syntaxin by applying BoNT/C (Hayashi et al., 1994).

Recordings were made from CA1 pyramidal neurons in current-clamp mode. Similarly to Figures 2 and 3, the electrodes were filled with Alexa 594 hydrazide (250 $\mu \mathrm{M}$ ) and the $\mathrm{Ca}^{2+}$ indicator Fluo-5F (200 $\mu \mathrm{M})$. In addition, the electrodes contained light chain BoNT/C (5 nM), which was infused into CA1 neurons with the dyes. After 35 min of whole-cell recording to allow diffusion of the toxin and the dyes throughout the neuron and its axon, $200 \mathrm{ac}-$ tion potentials $(1 \mathrm{~Hz})$ were evoked by short depolarizing current pulses $(2 \mathrm{~ms})$ through the patch electrode. This was done to eliminate any residual primed vesicles whose SNARE complexes are known to prevent BoNT/C access to its target, syntaxin (Hayashi et al., 1994). Presynaptic varicosities were identified as in Figures 2 and 3 and subsequently line scanned with $488 \mathrm{~nm}$ excitation during single action potentials. The 5- $\mathrm{HT}_{1 \mathrm{~B}} \mathrm{R}$ agonist CP93129 (1 $\mu \mathrm{M}$; Fig. 9a,d) now significantly inhibited $\mathrm{Ca}^{2+}$ transients in all of the terminals recorded (to $52 \pm 7 \%$ of control amplitude $n=8$; not significantly different from the effect of baclofen under control conditions). Like baclofen, this inhibition was not due to a failure of action potentials to evoke presynaptic responses, because in all cases an identifiable $\mathrm{Ca}^{2+}$ transient was evoked by stimulation in single varicosities before and during application of CP93129. Thus, $5-\mathrm{HT}_{1 \mathrm{~B}} \mathrm{Rs}$ inhibit $\mathrm{Ca}^{2+}$ entry after syntaxin cleavage.

It has been demonstrated that preexisting $\mathrm{G} \beta \gamma$ modulation of $\mathrm{Ca}^{2+}$ channels in expression systems is reduced by BoNT/C (Zamponi et al., 1997; Jarvis et al., 2000). It is important to consider that in the latter experiments only the SNARE complex proteins, plus $\mathrm{Ca}^{2+}$ channels and $\mathrm{G} \beta \gamma$, were present. Intact synapses, in contrast, represent a substantially more complex situation, in which BoNT/C in synapses cleaves syntaxin, but consequently prevents SNARE formation and further vesicle priming. Therefore, we determined whether pretreatment with BoNT/C modifies baclofen inhibition of $\mathrm{Ca}^{2+}$ transients. In cells infused with BoNT/C and stimulated (200 action potentials) identically to experiments with CP93129, baclofen $(10 \mu \mathrm{M})$ inhibited presynaptic $\mathrm{Ca}^{2+}$ transients simi-

larly to controls without BoNT/C (to $55 \pm 6 \%, n=5$, compared with $56 \pm 7 \%$ with no BoNT/C treatment; Fig. $9 b, d)$.

To ensure that BoNT/C treatment and subsequent action potential-evoked depriming did not alter the $\mathrm{Ca}^{2+}$ transient amplitude, in a further three neurons recorded as above, $\mathrm{Ca}^{2+}$ transients were evoked after loading of the terminal but before application of
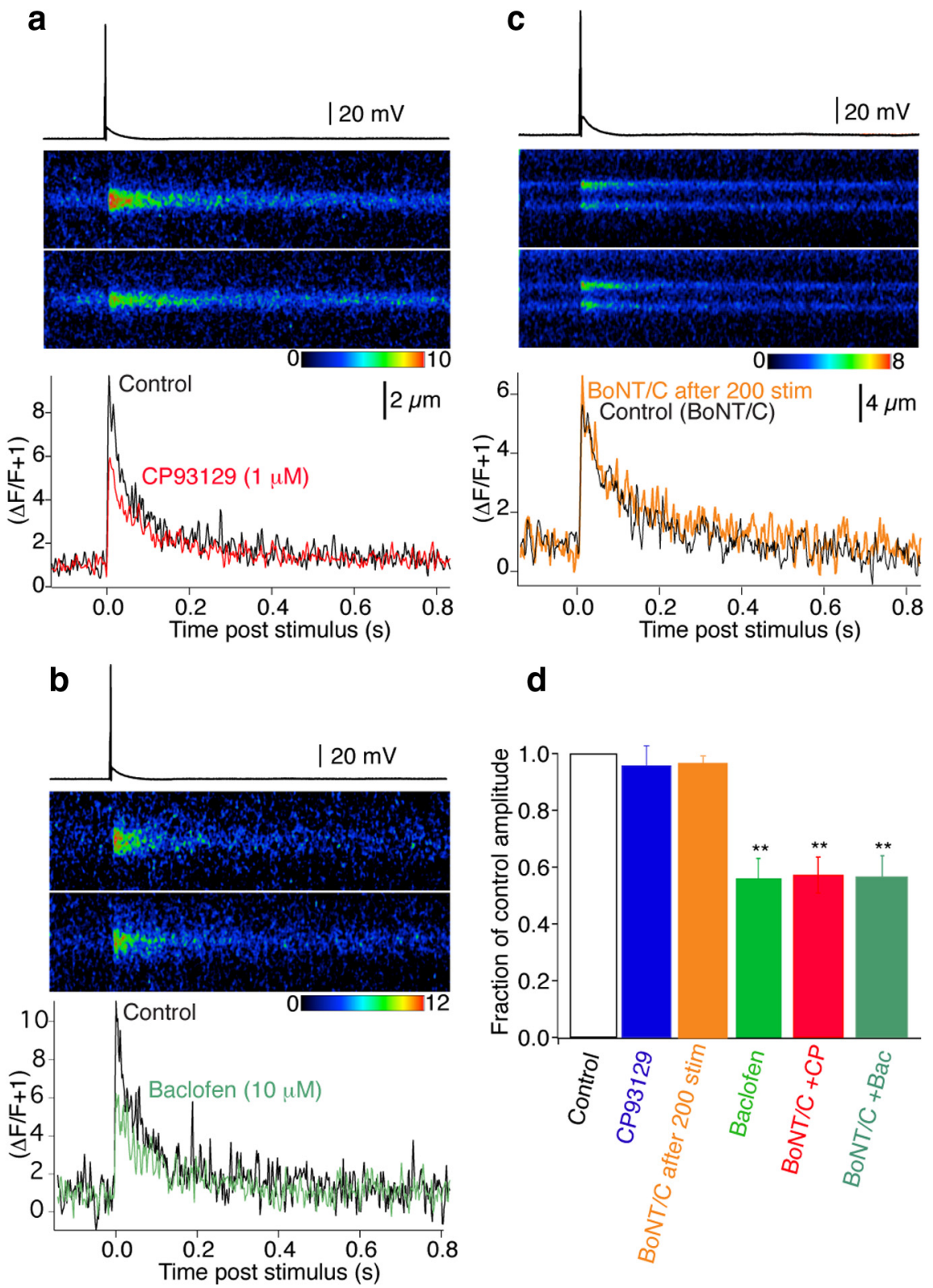

Figure 9. BoNT/C reveals $5-\mathrm{HT}_{1 \mathrm{~B}}$ receptor-mediated inhibition of presynaptic $\mathrm{Ca}^{2+}$ transients. CA1 pyramidal neurons were recorded with electrodes containing BoNT/C, Alexa, and Fluo-5F. Two hundred action potentials $(1 \mathrm{~Hz}, 35 \mathrm{~min}$ post whole cell) eliminated primed vesicles before recording. $\boldsymbol{a}$, Action potential-evoked $\mathrm{Ca}^{2+}$ transients recorded by line scanning over CA1 pyramidal neuron presynaptic varicosities in the subiculum (top trace Control, bottom in CP93129; 1 $\mu \mathrm{M}$ ). Graph (bottom) shows the integrated signals of three averaged responses in Control (black) and CP93129 (1 $\mu \mathrm{M}$; red). b, Similar CA1 presynaptic varicosity recording before (Control, black) and in baclofen (10 $\mu \mathrm{m}$; green) also after perfusion with BoNT/C. C, Similar CA1 presynaptic $\mathrm{Ca}^{2+}$ transient before (Control BoNT/C, black) following infusion of dyes and BoNT/C, and after 200 stimuli (BoNT/ after 200 stim, orange) Stimuli to exhaust the primed vesicle pool did not significantly alter the time course or amplitude of the transient. $\boldsymbol{d}$, Summary of BoNT/C and GPCR effects on $\mathrm{Ca}^{2+}$ transients (orange, 200 stimuli after BoNT/C application, $n=3$; blue, (P93129, $n=8$; green, baclofen, $n=7$ ) both in Control conditions. Then after priming eliminated with BoNT/C (red, CP93129, $n=5$; dark green, baclofen, $n=4)$. BoNT/C revealed reduction of $\mathrm{Ca}^{2+}$ transients in CP93129. ${ }^{* *} \mathrm{p}<0.01$.

200 action potential at $1 \mathrm{~Hz}$. This response was compared with that obtained after the $1 \mathrm{~Hz}$ period of stimulation to remove any primed vesicles. No significant alteration in the $\mathrm{Ca}^{2+}$ transient was seen (Fig. $9 c, d$; response amplitude after $1 \mathrm{~Hz}$ stimulation was $96 \pm 3 \%$ of control. Decay rate of the transient was also similar: before 200 stimuli $\tau=154 \pm 29 \mathrm{~ms}$, after 200 stimuli $\tau=147 \pm 30 \mathrm{~ms}$ ).

In these presynaptic terminals, it is likely that $\mathrm{GABA}_{\mathrm{B}} \mathrm{Rs}$ and $5-\mathrm{HT}_{1 \mathrm{~B}} \mathrm{Rs}$ functionally colocalize within the same terminals. 


\section{a}
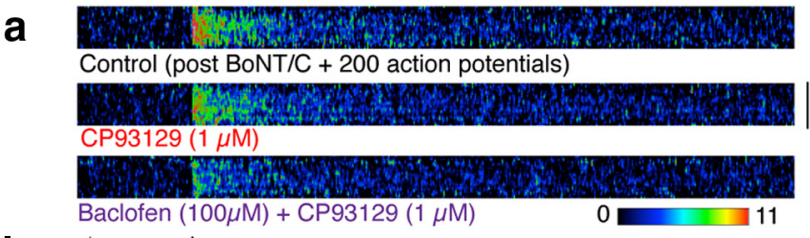

b
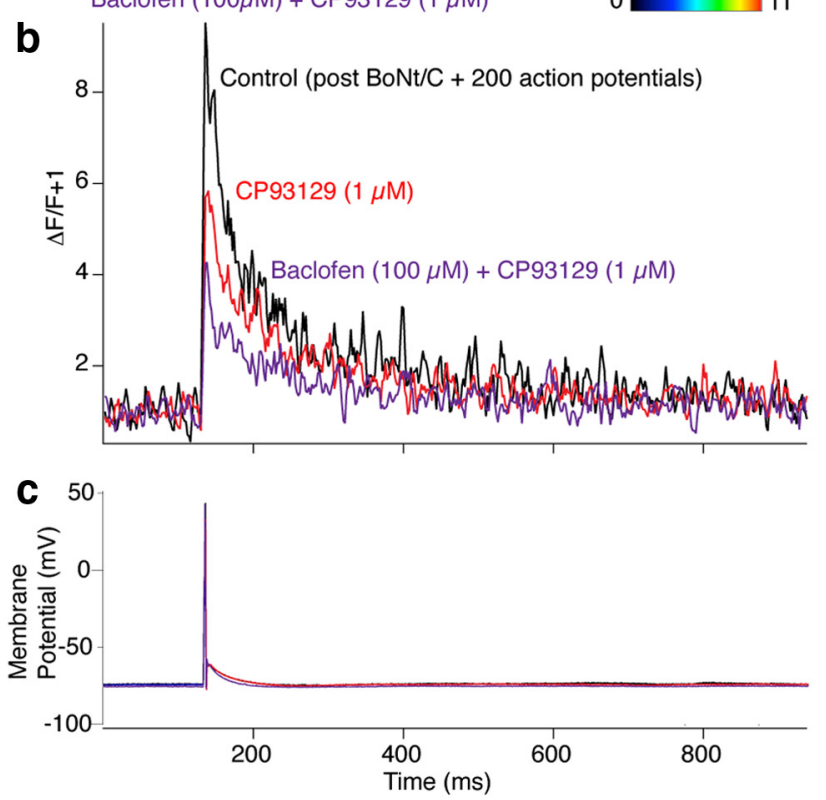

d

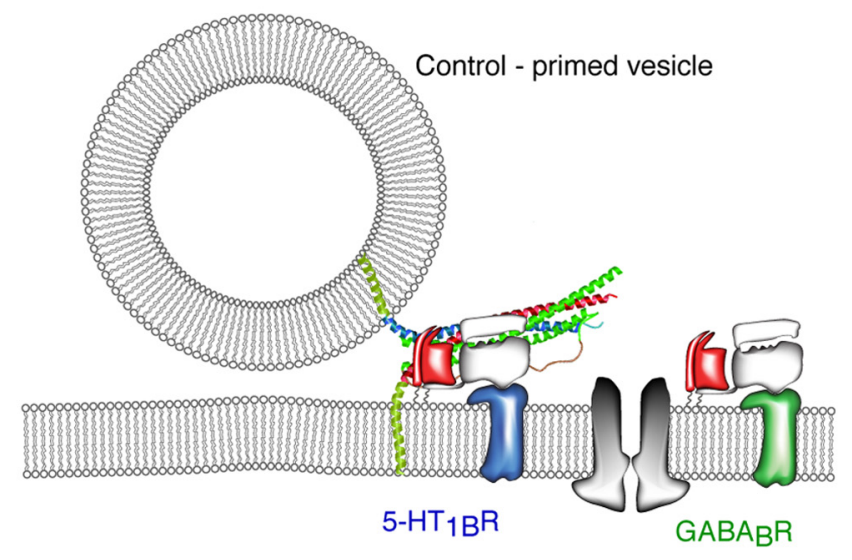

e

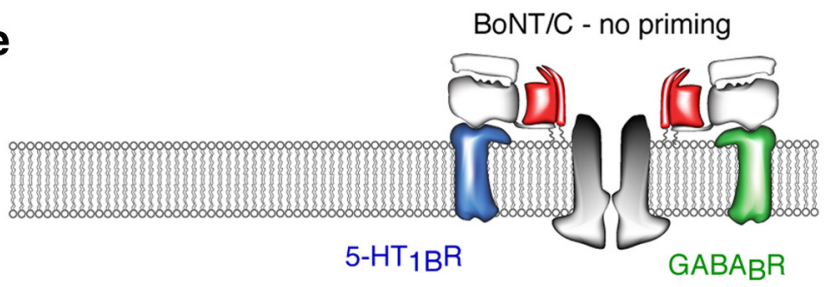

Figure 10. $5-\mathrm{HT}_{1 \mathrm{~B}} \mathrm{Rs}$ and $\mathrm{GABA}_{\mathrm{B}} \mathrm{Rs}$ are located on the same presynaptic terminals. CA1 pyramidal neurons were recorded with electrodes containing BoNT/C, Alexa, and Fluo-5F. Two hundred action potentials ( $1 \mathrm{~Hz}, 35$ min post whole cell) eliminated primed vesicles before recording. $\boldsymbol{a}$, Action potential-evoked Ca ${ }^{2+}$ transients recorded by line scanning over $C A 1$ pyramidal neuron presynaptic varicosities in the subiculum. (top trace, Control; (P93129, bottom; $1 \mu \mathrm{M})$. To make clear the sequential reduction of $\mathrm{Ca}^{2+}$ transient amplitude the image data from over the varicosity is shown as $\Delta F / F$ in pseudocolor after background subtraction from the images. $\boldsymbol{b}$, Graph shows the integrated signals of three averaged responses in Control (black), CP93129 (1 $\mu \mathrm{m}$; red), and in CP93129 (1 $\mu \mathrm{m}$ ) plus baclofen (100 $\mu \mathrm{m}$; purple). $\boldsymbol{c}$, Action potentials that evoked $\mathrm{Ca}^{2+}$ transients in $\boldsymbol{a}$ and $\boldsymbol{b}$. $\boldsymbol{d}$, Schematic of presynaptic GPCR targets. At primed vesicles 5 -HT ${ }_{1 \mathrm{~B}} \mathrm{Rs}$ and their associated $\mathrm{G}$-proteins interact with SNARE C terminals. $\mathrm{GABA}_{\mathrm{B}} \mathrm{Rs}$ interact with $\mathrm{Ca}^{2+}$ channels. $e$, BoNT/C treatment prevents priming, freeing 5 - $\mathrm{HT}{ }_{1 \mathrm{~B}} \mathrm{Rs}^{2}$ to modulate $\mathrm{Ca}^{2+}$ channels similarly to $\mathrm{GABA}_{\mathrm{B}} \mathrm{Rs}$.

For imaging experiments, all recorded terminals $(n=12$ in total) in which baclofen was applied alone showed inhibition of $\mathrm{Ca}^{2+}$ entry, while after BoNT/C treatment all eight tested terminals showed inhibition of $\mathrm{Ca}^{2+}$ entry by CP93129. The probability of randomly sampling only single receptor-expressing terminals would be extremely low $(p=0.0007$ and $p=0.004$, for $\mathrm{GABA}_{\mathrm{B}} \mathrm{Rs}$ and $5-\mathrm{HT}_{1 \mathrm{~B}} \mathrm{Rs}$, respectively) indicating coexpression of $\mathrm{GABA}_{\mathrm{B}}$ and $5-\mathrm{HT}_{1 \mathrm{~B}}$ receptors. Nevertheless, to confirm that both receptors are functional on the same presynaptic terminals four further $\mathrm{Ca}^{2+}$ imaging experiments were performed in which BoNT/C was applied to the recorded neurons to test efficacy of both $\mathrm{GABA}_{\mathrm{B}} \mathrm{Rs}$ and $5-\mathrm{HT}_{1 \mathrm{~B}} \mathrm{Rs}$ on the same terminal. Neurons were again recorded with electrodes containing BoNT/C, Fluo5F, and Alexa 594 hydrazide as above. In two of these neurons after identifying presynaptic varicosities, control $\mathrm{Ca}^{2+}$ transients were recorded. Baclofen $(1 \mu \mathrm{M})$ was applied, transients recorded, and baclofen washed from the superfusate (Baclofen reduced responses to 68 and $86 \%$ of control). Following wash 200 stimuli were applied to exhaust the primed vesicle pool. CP93129 (1 $\mu \mathrm{M})$ was applied to test whether responses could be inhibited (responses were inhibited to 36 and 55\% of the pre-CP93129 control response). In a further two experiments similar recordings were made. However, after identification of the presynaptic varicosity, 200 stimuli were immediately applied to exhaust the synaptic vesicle pool (Fig. $10 a-c$ ). Control $\mathrm{Ca}^{2+}$ transients were recorded and after CP93129 (1 $\mu \mathrm{M})$ was applied the responses were reduced to 58 and $56 \%$ of control. CP93129 has proved very diffi- cult to wash from the superfusate, thus a high dose of baclofen $(100 \mu \mathrm{M})$ was applied to test whether a further reduction in the $\mathrm{Ca}^{2+}$ transient could be recorded. Baclofen reduced the remaining responses by a further 58 and $75 \%$ of the responses in CP93129 (Fig. 10a,b). Baclofen caused a slight hyperpolarization of the recorded neuron; however, this did not prevent the firing of a somatic action potential (Fig. 10c), and in each case this action potential evoked a measurable $\mathrm{Ca}^{2+}$ transient at the presynaptic varicosity, demonstrating no spike failure (Fig. 3h). The CP93129 and baclofen-dependent inhibition of $\mathrm{Ca}^{2+}$ transients at the same presynaptic varicosities confirms that $\mathrm{GABA}_{\mathrm{B}} \mathrm{Rs}$ and $5-\mathrm{HT}_{1 \mathrm{~B}} \mathrm{Rs}$ are found at the same synapse (Fig. $10 d)$.

\section{Discussion}

GPCR-mediated inhibition of neurotransmitter release at presynaptic terminals (Starke, 1972) is considered ubiquitous (de Jong and Verhage, 2009). However, GPCRs may inhibit release by a number of mechanisms. In this study we have demonstrated two such mechanisms mediated by distinct $\mathrm{G} \alpha_{\mathrm{i} / \mathrm{o}}$-coupled receptors that coexist on CA1 pyramidal neuron presynaptic terminals: $\mathrm{GABA}_{\mathrm{B}} \mathrm{R}$-mediated inhibition of $\mathrm{Ca}^{2+}$ channels and $5-\mathrm{HT}_{1 \mathrm{~B}} \mathrm{R}$ mediated $G \beta \gamma$ interaction with the SNARE complex. We propose that the SNARE complex itself segregates these signaling pathways (Fig. 10d).

GPCRs can regulate neurotransmitter release by modifying presynaptic $\mathrm{Ca}^{2+}$ entry (Wu and Saggau, 1995) by a membrane delim- 
ited action of G $\beta \gamma$ on $\mathrm{Ca}^{2+}$ channels (Herlitze et al., 1996; Tedford and Zamponi, 2006) or alternatively by pathways that neither alter, nor require $\mathrm{Ca}^{2+}$ entry. These latter effects were first revealed by receptor-mediated inhibition of spontaneous release events (mEPSCs) independently of evoked $\mathrm{Ca}^{2+}$ entry and have been identified in the peripheral and central nervous systems (Silinsky, 1984; Stephens, 2009). Similar receptors may mediate both these forms of presynaptic inhibition. For example, $\mathrm{GABA}_{\mathrm{B}} \mathrm{Rs}$ are typically thought to inhibit $\mathrm{Ca}^{2+}$ entry (Wu and Saggau, 1995; Takahashi et al., 1998) but can also modify spontaneous event frequencies independently of $\mathrm{Ca}^{2+}$ entry (Kabashima et al., 1997). In hippocampus, $\mathrm{GABA}_{B}$ Rs have been implicated in both effects within the CA3 region (Lei and McBain, 2003). A third mechanism by which $G \beta \gamma$ inhibits neurotransmitter release by directly interacting with the SNARE complex has also been identified. 5- $\mathrm{HT}_{1 \mathrm{~B}}$ Rs (Blackmer et al., 2001; Takahashi et al., 2001), noradrenergic $\alpha_{2 \mathrm{~A}}$ Rs (Delaney et al., 2007), and mGluRs (Zhang et al., 2011; Upreti et al., 2013) may all act via this mechanism, which does not involve a change in presynaptic $\mathrm{Ca}^{2+}$ entry. Instead $\mathrm{G} \beta \gamma$ acts directly in the pathway of $\mathrm{Ca}^{2+}$-evoked exocytosis by interfering with $\mathrm{Ca}^{2+}$-dependent synaptotagmin binding to SNARE complexes (Blackmer et al., 2001; Gerachshenko et al., 2005; Delaney et al., 2007; Yoon et al., 2007).

$\mathrm{G} \beta \gamma$ interactions in the presynaptic terminal are modified by the release machinery itself. Membrane delimited actions of G $\beta \gamma$ on $\mathrm{Ca}^{2+}$ channels may be augmented by a direct interaction of $\mathrm{G} \beta \gamma$ with various release machinery proteins (Dunlap and Fischbach, 1978; Holz et al., 1989; Herlitze et al., 1996; Ikeda, 1996). For example, SNARE complexes, $\mathrm{Ca}^{2+}$ channels, and $\mathrm{G} \beta \gamma$ (Jarvis et al., 2002) may interact to augment $\mathrm{G} \beta \gamma$-mediated inhibition of $\mathrm{Ca}^{2+}$ channels, while GPCR-mediated inhibition of $\mathrm{Ca}^{2+}$ entry can be prevented by BoNT/C cleavage of syntaxin 1A in ciliary ganglion neurons (Stanley and Mirotznik, 1997). However, GPCRmediated $\mathrm{Ca}^{2+}$ channel inhibition is also seen in heterologous expression systems such as COS-7 cells with no coexpression of SNARE complex proteins and in isolated membrane patches with no presynaptic structures (Meir et al., 2000), indicating that formation of a complex with SNARE proteins is not required for modulation. Another presynaptic protein, cysteine string protein, can also augment $\mathrm{G} \beta \gamma$-mediated voltage-dependent inhibition of $\mathrm{Ca}^{2+}$ channels (Magga et al., 2000) while the ancillary $\mathrm{Ca}^{2+}$ channel subunits $\left(\mathrm{Ca}_{v} \beta\right)$ promote voltage-dependent Gprotein modulation of $\mathrm{Ca}^{2+}$ channels (Dresviannikov et al., 2009). Perhaps any one of these or other protein-protein interactions may predispose $\mathrm{Ca}^{2+}$ channels to be modulated by $\mathrm{G} \beta \gamma$. Of these, interaction with intact syntaxin $1 \mathrm{~A}$ is one, but clearly structural relationships with other proteins are essential for GPCR modulation of $\mathrm{Ca}^{2+}$ channels. In this study we show that $\mathrm{GABA}_{\mathrm{B}} \mathrm{Rs}$ substantially modulate $\mathrm{Ca}^{2+}$ transients in hippocampal nerve terminals, even after cleavage of syntaxin $1 \mathrm{~A}$ by treatment with BoNT/C.

It is less clear whether interacting proteins are necessary for $\mathrm{G} \beta \gamma$ to inhibit neurotransmitter release by its direct, but $\mathrm{Ca}^{2+}$. synaptotagmin-dependent, action on the SNARE complex (Blackmer et al., 2001; Takahashi et al., 2001). This inhibition involves competition between $\mathrm{G} \beta \gamma$ and synaptotagmin for binding to the SNARE complex, and has been characterized by sensitivity to BoNT/A toxin (Blackmer et al., 2005; Gerachshenko et al., 2005; Delaney et al., 2007; Zhang et al., 2011), which alters the relative affinities of $\mathrm{Ca}^{2+}$-synaptotagmin and $\mathrm{G} \beta \gamma$ to the SNARE complex (Yoon et al., 2007).

$5-\mathrm{HT}_{1 \mathrm{~B}} \mathrm{Rs}$ clearly inhibit release from CA1 neurons by using this direct interaction with the SNARE complex (Fig. 10d). The evidence for this comes from a number of results that we have presented in this study. $5-\mathrm{HT}_{1 \mathrm{~B}} \mathrm{Rs}$ strongly inhibit neurotransmitter release with no effect on presynaptic $\mathrm{Ca}^{2+}$ entry measured directly from individual presynaptic terminals. $5-\mathrm{HT}_{1 \mathrm{~B}} \mathrm{R}$-mediated inhibition is prevented by pretreatment with BoNT/A, which modifies competition between $\mathrm{G} \beta \gamma$ and $\mathrm{Ca}^{2+}$-synaptotagmin at the $\mathrm{C}$-terminal region of SNARE complexes. We also show that, in contrast to $G_{A B A} R$, these receptors do not modify $\mathrm{Sr}^{2+}$-evoked release. This is significant because, unlike $\mathrm{Ca}^{2+}$ as shown in this study and in earlier work (Bhalla et al., 2005), $\mathrm{Sr}^{2+}$ does not cause synaptotagmin binding to SNARE complexes leaving no direct target for $\mathrm{G} \beta \gamma$ to interfere with exocytosis. Together with earlier work indicating that $\mathrm{G} \beta \gamma$ can compete with $\mathrm{Ca}^{2+}$-dependent synaptotagmin binding to the C-terminal region of the SNARE complex (Blackmer et al., 2005; Gerachshenko et al., 2005; Yoon et al., 2007; Wells et al., 2012), these data imply that $5-\mathrm{HT}_{1 \mathrm{~B}} \mathrm{Rs}$ cause a direct interaction of $\mathrm{G} \beta \gamma$ on SNARE complexes. Finally, $5-\mathrm{HT}_{1 \mathrm{~B}} \mathrm{Rs}$ do not modify spontaneous event frequencies. However, the receptor clearly interferes with $\mathrm{Ca}^{2+}$-dependent release-albeit not by altering $\mathrm{Ca}^{2+}$ entry but instead by altering the interaction of $\mathrm{Ca}^{2+}$-synaptotagmin with the SNARE complex. These data also indicate that G $\beta \gamma$ and Doc2, a proposed mediator of spontaneous release (Groffen et al., 2010; Pang et al., 2011), do not share a binding site on SNARE complexes. G $\beta \gamma$ interacts with the very C-terminal region of SNAP-25, overlapping the C-terminal region of the synaptotagmin I interaction site (Blackmer et al., 2005; Yoon et al., 2007; Wells et al., 2012). Perhaps Doc2 interacts at a less C-terminal region of the SNARE complex (Groffen et al., 2010). Since $\mathrm{Sr}^{2+}$-evoked asynchronous release is also likely mediated by Doc2 (albeit different isoforms; Pang et al., 2011), and not synaptotagmin I, this could also explain why $5-\mathrm{HT}_{1 \mathrm{~B}} \mathrm{R}$ has no effect on asynchronous release.

The effect of $\mathrm{GABA}_{\mathrm{B}} \mathrm{Rs}$ is much simpler. These receptors substantially inhibit $\mathrm{Ca}^{2+}\left(\right.$ and $\mathrm{Sr}^{2+}$ ) entry to the presynaptic terminal. $\mathrm{GABA}_{\mathrm{B}} \mathrm{Rs}$ inhibit $\mathrm{Ca}^{2+}$ entry sufficiently to account for baclofen's effect on EPSCs if a fourth power relationship couples $\mathrm{Ca}^{2+}$ to exocytosis (Dodge and Rahamimoff, 1967).

We propose that functional separation of these pathways is provided by a microarchitecture, by which we mean $\mathrm{G} \beta \gamma$ prefers its nearest effector, as determined by the location of the associated GPCRs within the active zone. In synapses, $\mathrm{Ca}^{2+}$ channels may localize to SNARE complex $\mathrm{N}$ terminus (Jarvis et al., 2000, 2002). GPCRs, particularly $\mathrm{GABA}_{\mathrm{B}} \mathrm{Rs}$ (Padgett and Slesinger, 2010), form molecular machines by complexing with effectors and downstream targets, including $\mathrm{Ca}^{2+}$ channels (Park et al., 2010). Indeed, the $\mathrm{GB} 1 \mathrm{GABA}_{\mathrm{B}} \mathrm{R}$ subunit $\mathrm{C}$-terminal region is required for the receptor to associate with $\mathrm{Ca}^{2+}$ channels and to fully inhibit neurotransmitter release (Laviv et al., 2011). Similarly, in the case of 5- $\mathrm{HT}_{1 \mathrm{~B}} \mathrm{Rs}$ (Svenningsson et al., 2006), association of the receptor to molecular targets is required for functional inhibition of neurotransmitter release. $G \beta \gamma$, liberated by $5-\mathrm{HT}_{1 \mathrm{~B}} \mathrm{Rs}$, targets SNARE complex C-terminals to inhibit release (Blackmer et al., 2001, 2005; Gerachshenko et al., 2005). This result places effectors of $5-\mathrm{HT}_{1 \mathrm{~B}} \mathrm{Rs}$ and $\mathrm{GABA}_{\mathrm{B}} \mathrm{Rs}$ at opposite ends of primed SNARE complexes, and this separation appears to be sufficient to confer $G \beta \gamma$ specificity.

Perhaps SNARE complexes functionally separate targets of G $\beta \gamma$. G-protein or GPCR interactions with the SNARE complex may prevent $5-\mathrm{HT}_{1 \mathrm{~B}} \mathrm{R}$-mediated $\mathrm{G} \beta \gamma$ release from interacting with $\mathrm{Ca}^{2+}$ channels but not $\mathrm{GABA}_{\mathrm{B}} \mathrm{R}$ released $\mathrm{G} \beta \gamma$. Physical disruption of this microarchitecture by cleavage of syntaxin and subsequent disruption of vesicle priming with BoNT/C reveals equally effective targeting of $\mathrm{Ca}^{2+}$ channels by both receptors (Fig. 10e). Thus, receptor selectivity to their respective targets is 
not necessarily a property of a particular $\mathrm{G} \beta \gamma$ isoform, but may be a function of the structure in which the signal transduction cascade is embedded. BoNT/C treatment has also been previously shown to modify $\mathrm{Ca}^{2+}$ entry to presynaptic terminals (Bergsman and Tsien, 2000; Degtiar et al., 2000), albeit at a much slower time course than recorded in this study. It is conceivable that an alteration of the nanodomains of $\mathrm{Ca}^{2+}$ channels may also alter their availability to $\mathrm{G} \beta \gamma$ in the terminal. However, the loss of primed vesicles by stimulation after BoNT/C application did not alter $\mathrm{Ca}^{2+}$ entry, and the effect of baclofen on this $\mathrm{Ca}^{2+}$ entry was also not altered by BoNT/C treatment. When $5-\mathrm{HT}_{1 \mathrm{~B}} \mathrm{Rs}$ and their effector $\mathrm{G} \beta \gamma$ are no longer anchored to their target at the C-terminal region of the SNARE complex G $\beta \gamma$ may inhibit presynaptic $\mathrm{Ca}^{2+}$ channels. Similarly, presynaptic $\mathrm{Ca}^{2+}$ channels will also no longer be associated with SNARE complexes (Fig. $10 d, e)$. Of course, ultimately, properties of this signal transduction system must govern its target during vesicle priming. These results do not exclude the possibility that $G \beta \gamma$ identity plays a role in effector targeting. Indeed, there is precedent for such specificity (Macrez-Leprêtre et al., 1997; Wu et al., 1998; Mahon et al., 2006). If formation of primed SNARE complexes ensures G-protein target specificity, then priming must take just milliseconds to recruit modulatory proteins to the correct region of the SNARE complex as it is formed.

\section{References}

Bai J, Wang CT, Richards DA, Jackson MB, Chapman ER (2004) Fusion pore dynamics are regulated by synaptotagmin ${ }^{*}$ t-SNARE interactions. Neuron 41:929-942. CrossRef Medline

Bergsman JB, Tsien RW (2000) Syntaxin modulation of calcium channels in cortical synaptosomes as revealed by botulinum toxin C1. J Neurosci 20:4368-4378. Medline

Bhalla A, Tucker WC, Chapman ER (2005) Synaptotagmin isoforms couple distinct ranges of $\mathrm{Ca} 2+, \mathrm{Ba} 2+$, and $\mathrm{Sr} 2+$ concentration to SNAREmediated membrane fusion. Mol Biol Cell 16:4755-4764. CrossRef Medline

Blackmer T, Larsen EC, Takahashi M, Martin TF, Alford S, Hamm HE (2001) G protein betagamma subunit-mediated presynaptic inhibition: regulation of exocytotic fusion downstream of Ca2 + entry. Science 292: 293-297. CrossRef Medline

Blackmer T, Larsen EC, Bartleson C, Kowalchyk JA, Yoon EJ, Preininger AM, Alford S, Hamm HE, Martin TF (2005) G protein betagamma directly regulates SNARE protein fusion machinery for secretory granule exocytosis. Nat Neurosci 8:421-425. Medline

Brown DA, Sihra TS (2008) Presynaptic signaling by heterotrimeric G-proteins. Handb Exp Pharmacol 207-260. Medline

Catterall WA, Few AP (2008) Calcium channel regulation and presynaptic plasticity. Neuron 59:882-901. CrossRef Medline

Cox CL, Denk W, Tank DW, Svoboda K (2000) Action potentials reliably invade axonal arbors of rat neocortical neurons. Proc Natl Acad Sci U S A 97:9724-9728. CrossRef Medline

Degtiar VE, Scheller RH, Tsien RW (2000) Syntaxin modulation of slow inactivation of N-type calcium channels. J Neurosci 20:4355-4367. Medline

de Jong AP, Verhage M (2009) Presynaptic signal transduction pathways that modulate synaptic transmission. Curr Opin Neurobiol 19:245-253. CrossRef Medline

Delaney AJ, Crane JW, Sah P (2007) Noradrenaline modulates transmission at a central synapse by a presynaptic mechanism. Neuron $56: 880-892$. CrossRef Medline

Dodge FA Jr, Rahamimoff R (1967) Co-operative action a calcium ions in transmitter release at the neuromuscular junction. J Physiol 193:419432. Medline

Dresviannikov AV, Page KM, Leroy J, Pratt WS, Dolphin AC (2009) Determinants of the voltage dependence of $\mathrm{G}$ protein modulation within calcium channel beta subunits. Pflugers Arch 457:743-756. CrossRef Medline

Dunlap K, Fischbach GD (1978) Neurotransmitters decrease the calcium component of sensory neurone action potentials. Nature 276:837-839. CrossRef Medline

Fang Q, Berberian K, Gong LW, Hafez I, Sørensen JB, Lindau M (2008) The role of the C terminus of the SNARE protein SNAP-25 in fusion pore opening and a model for fusion pore mechanics. Proc Natl Acad Sci U S A 105:15388-15392. CrossRef Medline

Ford CE, Skiba NP, Bae H, Daaka Y, Reuveny E, Shekter LR, Rosal R, Weng G, Yang CS, Iyengar R, Miller RJ, Jan LY, Lefkowitz RJ, Hamm HE (1998) Molecular basis for interactions of $\mathrm{G}$ protein betagamma subunits with effectors. Science 280:1271-1274. CrossRef Medline

Gerachshenko T, Blackmer T, Yoon EJ, Bartleson C, Hamm HE, Alford S (2005) Gbetagamma acts at the C terminus of SNAP-25 to mediate presynaptic inhibition. Nat Neurosci 8:597-605. CrossRef Medline

Gerachshenko T, Schwartz E, Bleckert A, Photowala H, Seymour A, Alford S (2009) Presynaptic G-protein-coupled receptors dynamically modify vesicle fusion, synaptic cleft glutamate concentrations, and motor behavior. J Neurosci 29:10221-10233. CrossRef Medline

Groffen AJ, Martens S, Díez Arazola R, Cornelisse LN, Lozovaya N, de Jong AP, Goriounova NA, Habets RL, Takai Y, Borst JG, Brose N, McMahon HT, Verhage M (2010) Doc2b is a high-affinity Ca2 + sensor for spontaneous neurotransmitter release. Science 327:1614-1618. CrossRef Medline

Hayashi T, McMahon H, Yamasaki S, Binz T, Hata Y, Südhof TC, Niemann H (1994) Synaptic vesicle membrane fusion complex: action of clostridial neurotoxins on assembly. EMBO J 13:5051-5061. Medline

Herlitze S, Garcia DE, Mackie K, Hille B, Scheuer T, Catterall WA (1996) Modulation of $\mathrm{Ca} 2+$ channels by G-protein beta gamma subunits. Nature 380:258-262. CrossRef Medline

Holz GG 4th, Kream RM, Spiegel A, Dunlap K (1989) G proteins couple alpha-adrenergic and GABAb receptors to inhibition of peptide secretion from peripheral sensory neurons. J Neurosci 9:657-666. Medline

Ikeda SR (1996) Voltage-dependent modulation of N-type calcium channels by G-protein beta gamma subunits. Nature 380:255-258. CrossRef Medline

Jackson MB, Redman SJ (2003) Calcium dynamics, buffering, and buffer saturation in the boutons of dentate granule-cell axons in the hilus. J Neurosci 23:1612-1621. Medline

Jarvis SE, Magga JM, Beedle AM, Braun JE, Zamponi GW (2000) G protein modulation of N-type calcium channels is facilitated by physical interactions between syntaxin 1A and Gbetagamma. J Biol Chem 275:63886394. CrossRef Medline

Jarvis SE, Barr W, Feng ZP, Hamid J, Zamponi GW (2002) Molecular determinants of syntaxin 1 modulation of N-type calcium channels. J Biol Chem 277:44399-44407. CrossRef Medline

Kabashima N, Shibuya I, Ibrahim N, Ueta Y, Yamashita H (1997) Inhibition of spontaneous EPSCs and IPSCs by presynaptic GABAB receptors on rat supraoptic magnocellular neurons. J Physiol 504:113-126. CrossRef Medline

Kavalali ET, Chung C, Khvotchev M, Leitz J, Nosyreva E, Raingo J, Ramirez DM (2011) Spontaneous neurotransmission: an independent pathway for neuronal signaling? Physiology 26:45-53. CrossRef Medline

Lai Y, Diao J, Liu Y, Ishitsuka Y, Su Z, Schulten K, Ha T, Shin YK (2013) Fusion pore formation and expansion induced by $\mathrm{Ca} 2+$ and synaptotagmin 1. Proc Natl Acad Sci U S A 110:1333-1338. CrossRef Medline

Laviv T, Vertkin I, Berdichevsky Y, Fogel H, Riven I, Bettler B, Slesinger PA, Slutsky I (2011) Compartmentalization of the GABAB receptor signaling complex is required for presynaptic inhibition at hippocampal synapses. J Neurosci 31:12523-12532. CrossRef Medline

Lei S, McBain CJ (2003) GABA B receptor modulation of excitatory and inhibitory synaptic transmission onto rat CA3 hippocampal interneurons. J Physiol 546:439-453. CrossRef Medline

Macrez-Leprêtre N, Kalkbrenner F, Morel JL, Schultz G, Mironneau J (1997) $\mathrm{G}$ protein heterotrimer Galpha13betalgamma3 couples the angiotensin AT1A receptor to increases in cytoplasmic $\mathrm{Ca} 2+$ in rat portal vein myocytes. J Biol Chem 272:10095-10102. CrossRef Medline

Magga JM, Jarvis SE, Arnot MI, Zamponi GW, Braun JE (2000) Cysteine string protein regulates $\mathrm{G}$ protein modulation of $\mathrm{N}$-type calcium channels. Neuron 28:195-204. CrossRef Medline

Mahon MJ, Bonacci TM, Divieti P, Smrcka AV (2006) A docking site for G protein betagamma subunits on the parathyroid hormone 1 receptor supports signaling through multiple pathways. Mol Endocrinol 20:136-146. Medline 
Mazzoni MR, Malinski JA, Hamm HE (1991) Structural analysis of rod GTP-binding protein, Gt. Limited proteolytic digestion pattern of Gt with four proteases defines monoclonal antibody epitope. J Biol Chem 266: 14072-14081. Medline

Meir A, Bell DC, Stephens GJ, Page KM, Dolphin AC (2000) Calcium channel beta subunit promotes voltage-dependent modulation of alpha $1 \mathrm{~B}$ by G beta gamma. Biophys J 79:731-746. CrossRef Medline

Mellow AM, Phillips TE, Silinsky EM (1978) On the conductance pathway traversed by strontium in mediating the asynchronous release of acetylcholine by motor nerve impulses. Br J Pharmacol 63:229-232. CrossRef Medline

Mellow AM, Perry BD, Silinsky EM (1982) Effects of calcium and strontium in the process of acetylcholine release from motor nerve endings. J Physiol 328:547-562. Medline

Michaeli A, Yaka R (2010) Dopamine inhibits GABA(A) currents in ventral tegmental area dopamine neurons via activation of presynaptic G-protein coupled inwardly-rectifying potassium channels. Neuroscience 165: 1159-1169. CrossRef Medline

Miller RJ (1998) Presynaptic receptors. Annu Rev Pharmacol Toxicol 38: 201-227. CrossRef Medline

Mizutani H, Hori T, Takahashi T (2006) 5-HT1B receptor-mediated presynaptic inhibition at the calyx of Held of immature rats. Eur J Neurosci 24:1946-1954. CrossRef Medline

Neher E, Augustine GJ (1992) Calcium gradients and buffers in bovine chromaffin cells. J Physiol 450:273-301. Medline

Otto H, Hanson PI, Chapman ER, Blasi J, Jahn R (1995) Poisoning by botulinum neurotoxin A does not inhibit formation or disassembly of the synaptosomal fusion complex. Biochem Biophys Res Commun 212:945952. CrossRef Medline

Padgett CL, Slesinger PA (2010) GABAB receptor coupling to G-proteins and ion channels. Adv Pharmacol 58:123-147. CrossRef Medline

Pang ZP, Bacaj T, Yang X, Zhou P, Xu W, Südhof TC (2011) Doc2 supports spontaneous synaptic transmission by a $\mathrm{Ca}(2+)$-independent mechanism. Neuron 70:244-251. CrossRef Medline

Park HW, Jung H, Choi KH, Baik JH, Rhim H (2010) Direct interaction and functional coupling between voltage-gated $\mathrm{CaV} 1.3 \mathrm{Ca} 2+$ channel and GABAB receptor subunit 2. FEBS Lett 584:3317-3322. CrossRef Medline

Pellegrini LL, O'Connor V, Betz H (1994) Fusion complex formation protects synaptobrevin against proteolysis by tetanus toxin light chain. FEBS Lett 353:319-323. CrossRef Medline

Phillips WJ, Cerione RA (1991) Labeling of the beta gamma subunit complex of transducin with an environmentally sensitive cysteine reagent. Use of fluorescence spectroscopy to monitor transducin subunit interactions. J Biol Chem 266:11017-11024. Medline

Scanziani M, Capogna M, Gähwiler BH, Thompson SM (1992) Presynaptic inhibition of miniature excitatory synaptic currents by baclofen and adenosine in the hippocampus. Neuron 9:919-927. CrossRef Medline

Sheng ZH, Rettig J, Takahashi M, Catterall WA (1994) Identification of a syntaxin-binding site on N-type calcium channels. Neuron 13:13031313. CrossRef Medline

Sheng ZH, Rettig J, Cook T, Catterall WA (1996) Calcium-dependent interaction of $\mathrm{N}$-type calcium channels with the synaptic core complex. Nature 379:451-454. CrossRef Medline

Shin OH, Rhee JS, Tang J, Sugita S, Rosenmund C, Südhof TC (2003) Sr2+ binding to the $\mathrm{Ca} 2+$ binding site of the synaptotagmin $1 \mathrm{C} 2 \mathrm{~B}$ domain triggers fast exocytosis without stimulating SNARE interactions. Neuron 37:99-108. CrossRef Medline

Silinsky EM (1984) On the mechanism by which adenosine receptor activation inhibits the release of acetylcholine from motor nerve endings. J Physiol 346:243-256. Medline

Silinsky EM (2008) Selective disruption of the mammalian secretory appa- ratus enhances or eliminates calcium current modulation in nerve endings. Proc Natl Acad Sci U S A 105:6427-6432. CrossRef Medline

Stanley EF, Mirotznik RR (1997) Cleavage of syntaxin prevents G-protein regulation of presynaptic calcium channels. Nature 385:340-343. CrossRef Medline

Starke K (1972) Influence of extracellular noradrenaline on the stimulationevoked secretion of noradrenaline from sympathetic nerves: evidence for an receptor-mediated feed-back inhibition of noradrenaline release. Naunyn Schmiedebergs Arch Pharmacol 275:11-23. CrossRef Medline

Stephens GJ (2009) G-protein-coupled-receptor-mediated presynaptic inhibition in the cerebellum. Trends Pharmacol Sci 30:421-430. CrossRef Medline

Svenningsson P, Chergui K, Rachleff I, Flajolet M, Zhang X, El Yacoubi M, Vaugeois JM, Nomikos GG, Greengard P (2006) Alterations in 5-HT1B receptor function by p11 in depression-like states. Science 311:77-80. CrossRef Medline

Takahashi M, Freed R, Blackmer T, Alford S (2001) Calcium influxindependent depression of transmitter release by 5-HT at lamprey spinal cord synapses. J Physiol 532:323-336. CrossRef Medline

Takahashi T (2005) Dynamic aspects of presynaptic calcium currents mediating synaptic transmission. Cell Calcium 37:507-511. CrossRef Medline

Takahashi T, Kajikawa Y, Tsujimoto T (1998) G-Protein-coupled modulation of presynaptic calcium currents and transmitter release by a GABAB receptor. J Neurosci 18:3138-3146. Medline

Tedford HW, Zamponi GW (2006) Direct G protein modulation of Cav2 calcium channels. Pharmacol Rev 58:837-862. CrossRef Medline

Upreti C, Zhang XL, Alford S, Stanton PK (2013) Role of presynaptic metabotropic glutamate receptors in the induction of long-term synaptic plasticity of vesicular release. Neuropharmacology 66:31-39. CrossRef Medline

Wang L, Armstrong WE (2012) Tonic regulation of GABAergic synaptic activity on vasopressin neurones by cannabinoids. J Neuroendocrinol 24:664-673. CrossRef Medline

Wells CA, Zurawski Z, Betke KM, Yim YY, Hyde K, Rodriguez S, Alford S, Hamm HE (2012) G $\beta \gamma$ inhibits exocytosis via interaction with critical residues on soluble $\mathrm{N}$-ethylmaleimide-sensitive factor attachment protein-25. Mol Pharmacol 82:1136-1149. CrossRef Medline

Wu G, Benovic JL, Hildebrandt JD, Lanier SM (1998) Receptor docking sites for G-protein betagamma subunits. Implications for signal regulation. J Biol Chem 273:7197-7200. CrossRef Medline

Wu LG, Saggau P (1995) GABAB receptor-mediated presynaptic inhibition in guinea-pig hippocampus is caused by reduction of presynaptic $\mathrm{Ca} 2+$ influx. J Physiol 485:649-657. Medline

Xu T, Binz T, Niemann H, Neher E (1998) Multiple kinetic components of exocytosis distinguished by neurotoxin sensitivity. Nat Neurosci 1:192200. CrossRef Medline

Xu-Friedman MA, Regehr WG (1999) Presynaptic strontium dynamics and synaptic transmission. Biophys J 76:2029-2042. CrossRef Medline

Yoon EJ, Gerachshenko T, Spiegelberg BD, Alford S, Hamm HE (2007) Gbetagamma interferes with $\mathrm{Ca} 2+$-dependent binding of synaptotagmin to the soluble N-ethylmaleimide-sensitive factor attachment protein receptor (SNARE) complex. Mol Pharmacol 72:1210-1219. CrossRef Medline

Zamponi GW, Bourinet E, Nelson D, Nargeot J, Snutch TP (1997) Crosstalk between $\mathrm{G}$ proteins and protein kinase $\mathrm{C}$ mediated by the calcium channel alpha1 subunit. Nature 385:442-446. CrossRef Medline

Zhang XL, Upreti C, Stanton PK (2011) G $\beta \gamma$ and the C terminus of SNAP-25 are necessary for long-term depression of transmitter release. PLoS One 6:e20500. CrossRef Medline

Zhang X, Kim-Miller MJ, Fukuda M, Kowalchyk JA, Martin TF (2002) $\mathrm{Ca} 2+$-dependent synaptotagmin binding to SNAP-25 is essential for Ca2+-triggered exocytosis. Neuron 34:599-611. CrossRef Medline 